\title{
Themes and Trends of Journal of Family and Economic Issues: A Review of Twenty Years (1988-2007)
}

Jeffrey P. Dew

Brigham Young University - Provo, jeff_dew@byu.edu

Follow this and additional works at: https://scholarsarchive.byu.edu/facpub

Part of the Other Social and Behavioral Sciences Commons

\section{Original Publication Citation}

Dew, J. P. (2008). Themes and trends of the Journal of Family and Economic Issues: A Review of Twenty Years (1988-2007). Journal of Family and Economic Issues, 29, 496-520.

\section{BYU ScholarsArchive Citation}

Dew, Jeffrey P., "Themes and Trends of Journal of Family and Economic Issues: A Review of Twenty Years (1988-2007)" (2008). Faculty Publications. 4509.

https://scholarsarchive.byu.edu/facpub/4509

This Peer-Reviewed Article is brought to you for free and open access by BYU ScholarsArchive. It has been accepted for inclusion in Faculty Publications by an authorized administrator of BYU ScholarsArchive. For more information, please contact ellen_amatangelo@byu.edu. 


\title{
Themes and Trends of Journal of Family and Economic Issues: A Review of Twenty Years (1988-2007)
}

\author{
Jeffrey Dew
}

Published online: 21 May 2008

(C) Springer Science+Business Media, LLC 2008

\begin{abstract}
This review article examines the progress and impact of the Journal of Family and Economic Issues (JFEI) between 1988-2007. Over the past 20 years, JFEI has become a major journal publishing articles on the relationship between families and economic systems. JFEI contributed to both the economic and family studies disciplines by publishing articles that explore the interface of these two disciplines. Between 1988 and 2007, $J F E I$ published articles on a variety of themes not often found in other economic or family studies journals such as family resource management, consumer attitudes and behaviors, and economic issues and family relationships. Other unique characteristics of JFEI include many collaborative multidisciplinary studies and many studies analyzing international or cross-cultural samples.
\end{abstract}

Keywords Consumer science $\cdot$ Family and economic issues $\cdot$ Journal review

In 1988, the editor and board of the journal Lifestyles: A Journal of Changing Patterns changed the focus of the journal and renamed it Lifestyles: Family and Economic Issues. In the vision of Charles "Chuck" Hennon, then the editor, the journal would publish "articles having as a central focus the interface between the family and economic systems" (Hennon 1988, 3). To more strongly emphasize the focus of the journal, the title became the Journal of Family and Economic Issues (JFEI) in 1992.

Dr. Hennon's and the editorial board's decision to shift the focus of the journal has proved quite prescient; during the two-decades since the change in focus in 1988, JFEI has grown substantially. A review in a separate journal showed that by the end of the 1990s, JFEI had become the top outlet of scholarship on consumer science research and published $62 \%$ more articles on consumer science research than the next-closest journal (Reynolds and Abdel-ghany 2001). Consequently, in only 10 years, JFEI managed to become a top

\footnotetext{
J. Dew $(\bowtie)$

Department of Sociology, University of Virginia, 542 Cabell Hall, P.O. Box 400766, Charlottesville, VA 22904-4766, USA

e-mail: jpd197@juno.com
} 
consumer science research journal by focusing on "the interface between the family and economic systems" (Hennon 1988, 3).

Since that review in 2001, JFEI has continued to grow. In 2003, the journal increased the number of pages in the volume by about 7\% (from about 380 to 405 pages) to accommodate the increased number of high-quality manuscript submissions. In 2004 and 2005, the number of pages increased by more than a third of 2003 levels to about 500 pages per volume. Finally, the 2006 and 2007 volumes had a 27\% increase over 2005 levels to roughly 700 pages per volume. The increase in the quantity of JFEI articles has not decreased their quality, however. The average acceptance rate between 2000 and 2005 is $32 \%$ (Xiao 2006). Thus, JFEI has grown in stature while maintaining the quality of the scholarship in its articles and is now a major outlet of research examining the relationship between family and economic issues.

Beyond the sheer number of publications, however, how has JFEI impacted the interdisciplinary field of family and economic research over the past 20 years? This article addresses this question. First, the method of the review is discussed. Second, JFEI's characteristics are considered, including research themes and the multidisciplinary and international/cross-cultural nature of JFEI, and notes how those characteristics contribute to family and economic research literature. In addition, this article reviews JFEI citation trends. Finally, an annotated bibliography is included in the appendix. It lists all JFEI articles published in 1988-2007 (excluding book reviews) categorized by the main theme.

\section{Method}

I examined every article published in JFEI between 1988 and 2007, excluding editorial remarks and book reviews. Thus, I reviewed a total of 420 articles. I read the abstracts and key words of each article to classify the studies' theme. In some cases I had to read substantial amounts of the study if the theme was not readily apparent. I did not have any preconception of possible classification themes prior to reviewing the articles. Rather, as articles began to coalesce into meaningful groups during the review, I named these groups. Some articles fit into more than one theme. In these cases I attempted to select the theme that the author(s) focused on the most. At the end of the review I assessed the themes, combined some that were closely related (e.g., division of labor, gender roles, and women's labor force participation), and classified articles that had been in a "miscellaneous" category.

To quantify multidisciplinary authorship, authors' departmental or institute affiliation was noted for each article. All articles with more than one author were then evaluated. If an article had more than one author and the authors had different departmental affiliations, the article was considered to have multidisciplinary authorship. Thus, for example, if a psychologist and sociologist co-authored a paper it was counted as multidisciplinary. If, however, a professor from a family and consumer sciences department coauthored a paper with a professor from a consumer studies department, the paper was not considered multidisciplinary.

To be considered international or cross-cultural, a study had to meet one of two conditions. The paper either had to have a non-U.S. sample, or have a U.S. sample with a substantial focus on race/ethnic minority individuals within the sample.

Finally, citation trends were assessed by using the citation counts of the articles in the online database scholar.google.com in October of 2007. I chose the scholar.google.com database because it does not omit some journals like other citation databases do, and 
because it is a resource available to all scholars rather than being exclusive. To obtain the citation rates, I first located each article on scholar.google.com. I then noted the number of citations for each article and whether each citation was outside or within JFEI. Then I averaged the number of citations in each volume. Because journal citations in the social sciences usually take time to accumulate, only the 1988-2004 citation rates were evaluated.

\section{Impact on the Field of Family and Economic Studies}

\section{Characteristics of JFEI}

\section{JFEI Themes}

The JFEI articles produced 15 themes. Ranging from Caregiving to Family Policy and from Consumer Attitudes and Behaviors to Employment and Work-Family Issues, these themes captured a wide range of topics related to the contact-points of family and economic issues (see Table 1). Perhaps not surprisingly, the themes of JFEI articles changed over time as different aspects of the family/economic-systems nexus have become more or less salient in society. For example, articles on work-family issues have steadily increased over-time, while articles on rural families have declined (Table 1).

Beyond the breadth of themes, JFEI articles covered many of them in depth. Ten of the 15 themes averaged one or more article per year. Given the focus of the journal, it is perhaps unsurprising that it published over 50 articles on family resource management between 1988 and 2007. However, the journal also published 40 articles on the division of

Table 1 Themes of articles in the Journal of Family and Economic Issues

\begin{tabular}{|c|c|c|c|c|c|}
\hline & $\begin{array}{l}\text { Articles in } \\
1988-1992\end{array}$ & $\begin{array}{l}\text { Articles in } \\
1993-1997\end{array}$ & $\begin{array}{l}\text { Articles in } \\
1998-2002\end{array}$ & $\begin{array}{l}\text { Articles in } \\
2003-2007\end{array}$ & Total \\
\hline Caregiving & 1 & 5 & 9 & 8 & 23 \\
\hline Consumer attitudes and behaviors & 3 & 8 & 3 & 9 & 23 \\
\hline Contraception, reproduction, sexual behavior & 6 & 3 & 2 & 3 & 14 \\
\hline $\begin{array}{l}\text { Division of labor, gender roles, women's } \\
\text { labor force participation }\end{array}$ & 14 & 5 & 9 & 12 & 40 \\
\hline Economic issues and family relationships & 12 & 5 & 2 & 19 & 38 \\
\hline Employment and work-family issues & 2 & 5 & 13 & 19 & 39 \\
\hline $\begin{array}{l}\text { Family-owned businesses, home based } \\
\text { employment }\end{array}$ & 12 & 3 & 8 & 6 & 29 \\
\hline Family policy & 5 & 15 & 5 & 8 & 33 \\
\hline Family resource management & 14 & 6 & 12 & 20 & 52 \\
\hline Health and health services & 4 & 5 & 3 & 5 & 17 \\
\hline Housing & 5 & 5 & 2 & 1 & 13 \\
\hline $\begin{array}{l}\text { Intergenerational or interhousehold } \\
\text { exchanges }\end{array}$ & 3 & 3 & 5 & 4 & 15 \\
\hline Poverty, public assistance & 1 & 5 & 6 & 15 & 27 \\
\hline Rural families & 8 & 6 & 0 & 1 & 15 \\
\hline Time use & 12 & 11 & 1 & 4 & 28 \\
\hline
\end{tabular}


labor, gender roles, or women's labor force participation during that time. Also notable were themes that rarely get play in other family journals such as family-owned businesses and at-home employment ( 29 articles) and the relationship between economic issues and family relationships (38 articles).

One unique aspect of JFEI was that often an entire issue focused on a specific theme. $J F E I$ averaged about one special issue per year. Like the themes, these topics of the special issues were diverse-from time use, to family-owned businesses, to risk taking, for example. Guest editors chaired these special issues; their unique perspective on a topic influenced the character of the issue. Although other journals also have thematic issues and guest editors from time to time, JFEI frequently published special issues to address gaps in the literature regarding family and economic issues.

\section{Multidisciplinary Authorship}

Similar to the number of different themes, JFEI authors represented many disciplines. Beyond consumer economics and family studies, JFEI authors' departmental affiliations ranged from psychology to political science and from nutrition to sociology. Further, JFEI has also welcomed authors that were not in academic settings; this practice has diversified the manuscripts submitted. Although less common, manuscripts from authors at nonacademic research centers, think tanks, and even large multinational entities (e.g., IBM, the World Bank) have enriched JFEI and helped broaden the examination of the relationship between economic and family issues.

Not only did JFEI publish articles from many disciplines, but JFEI authors often collaborated with individuals outside their discipline. For example, from 1988 to 2007, $57 \%$ of multi-author papers were written by collaborators in differing disciplines. In fact, the percent of multi-author papers that had multidisciplinary authorship was $50 \%$ or more in 14 of the 20 years (see Fig. 1). The percent of multidisciplinary authored papers never dropped below $40 \%$. Publishing multidisciplinary studies is clearly one of JFEI's strengths.

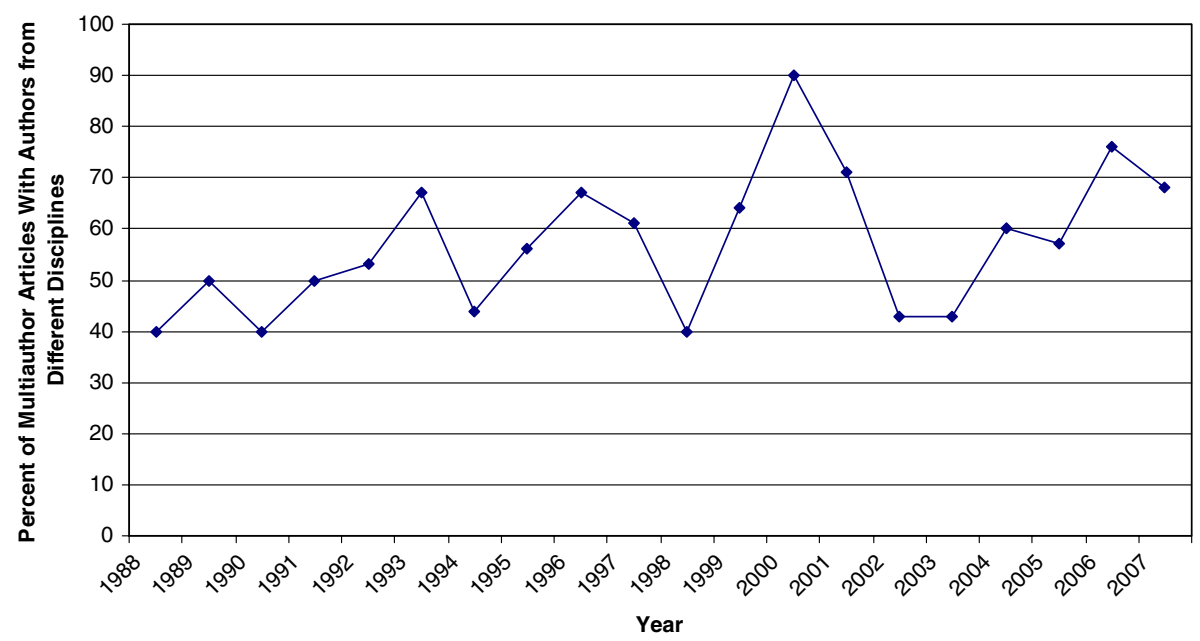

Fig. 1 Multidisciplinary authorship in the Journal of Family and Economic Issues 


\section{International/Cross-cultural Studies}

The final unique characteristic of JFEI articles is the emphasis on international and cross-cultural studies. JFEI averaged slightly over 5 international/cross-cultural articles per year between 1988 and 2007. However, the majority of international and crosscultural articles have been published since 1996 with many published in recent years (see Fig. 2).

Like some of the themes, many of the international or cross-cultural articles resulted from relevant social trends. Often, for example, international articles were published in special issues focusing on countries that experienced rapid economic change such as China and Poland. The cross-cultural articles are timely as well; many of them focus on the relationship between family and economic issues for Hispanic-Americans-now the U.S.'s second largest racial/ethnic group and one of the fastest growing. As noted below, publishing international and cross-cultural studies helps scholars understand the complexity of the economics/family relationship.

\section{Enhancing Scholarship}

These three characteristics of JFEI articles-breadth and depth of themes, multidisciplinary authorship, and international/cross-cultural studies-have positively influenced research on the relationship between economic issues and families. First, these characteristics of JFEI have provided an outlet for quality manuscripts that successfully bridge the gap between the two separate literatures of economics and family studies. For example, in a 25 year period, two well-known family-studies journals published only three articles related to family resource management (Israelsen and Hatch 2005). However, scholars

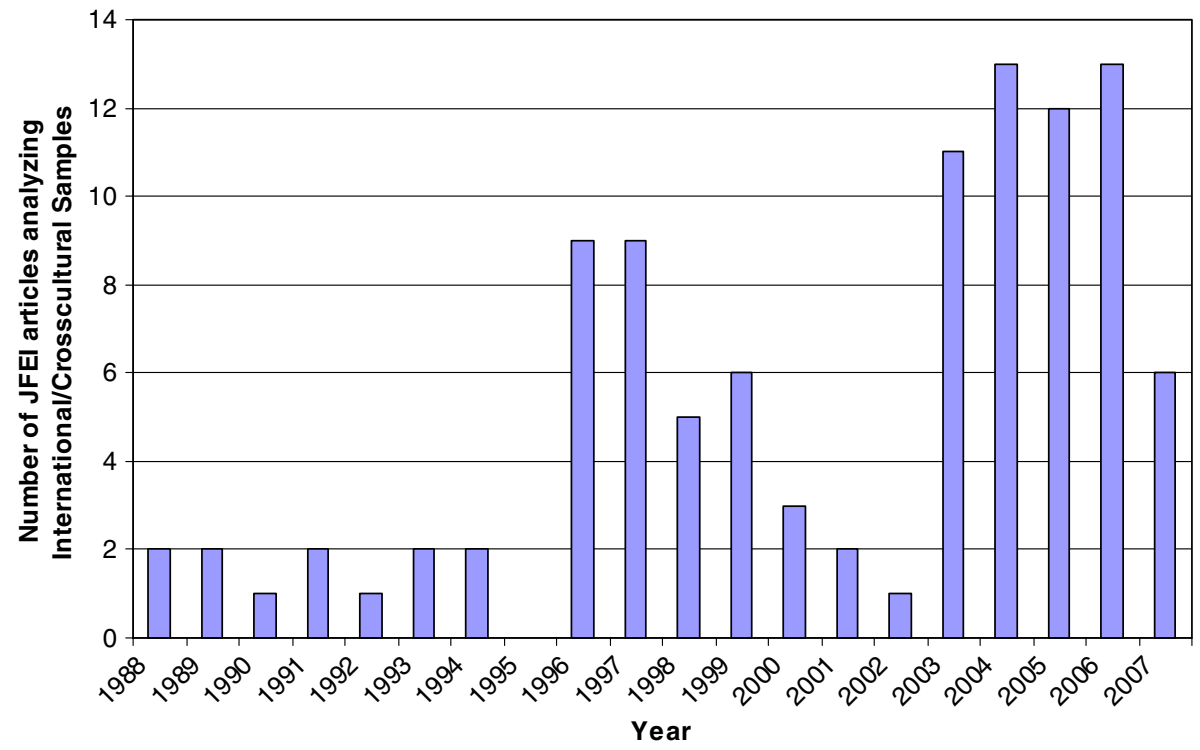

Fig. 2 International/Cross-cultural articles in the Journal of Family and Economic Issues 
have continued to call for more attention to the relationship between family resource management and family life (Daly 2003; Zelizer 1994). JFEI filled this gap and published over 50 articles in family resource management and an additional 38 articles on how economic issues influence family relations.

By publishing articles with many different family-economic themes and multidisciplinary collaborators, JFEI also managed to capture the complexity of the relationship between family and economic issues. As noted above, 57\% of multiauthor papers were written by collaborators who crossed disciplinary lines. Although the interface between economics and families encompasses aspects of economics, consumer finance, and family studies, multidisciplinary authorship helps to better examine this interface. When scholars from multiple disciplines collaborate, they bring different perspectives to the same research problem and help each other overcome any disciplinary "blind spots."

For example, economists and sociologists are not the only types of researchers needed to help understand work-family issues. Understanding such a complex relationship also necessitates the insights of psychologists, human resource specialists, and policy experts. Further, work-family issues do not just involve themes of economics, time use, and family relations. Rather, ideas about gender, care giving, and family resource management are also relevant. As an example of multidisciplinary authorship, an economist, a psychologist, and a human resource specialist collaborated to analyze how workers perceptions' of family-friendly policies differed across types of employment (Anderson et al. 2002). Because these three authors came from different backgrounds, they were able to synthesize three distinct areas related to their respective fields (e.g., perceptions-psychology, work-family policy-human resources, corporate practices-economics) and produce insights about work-family issues facing university employees.

Finally, by publishing articles focusing on international and cross-cultural populations, $J F E I$ advances understanding about the family-economic interface. For example, as noted above, many of the international publications focused on countries experiencing rapid economic change. Large economic shifts in countries provide case-studies for how families and macro-economic systems relate. These case-studies may refute or support various ideas on how families relate to economic systems leading to theoretic refinement. Further, international and cross-cultural studies provide insight as to how much of the relationship between families and economic issues are culturally determined. That is, to some extent the relationship between family and economic issues varies across cultures. For example, a recent study analyzed plans for future care among Latino and Anglo individuals (Delgadillo et al. 2004). By focusing on cross-cultural comparison, these scholars were able to demonstrate that older Latino individuals may lack knowledge about elder-care options in the U.S. This finding has practical implications, especially given the growing HispanicAmerican population in the U.S.

\section{Citation Trends}

Figure 3 shows the average citation trends of the articles in each volume from 1988 to 2007. The trend generally goes up from an average of about two citations per article in 1988 and 1989 to over six citations per article in 2000 and 2002. The upward trend became a downtrend in 2003 and 2004, however. 


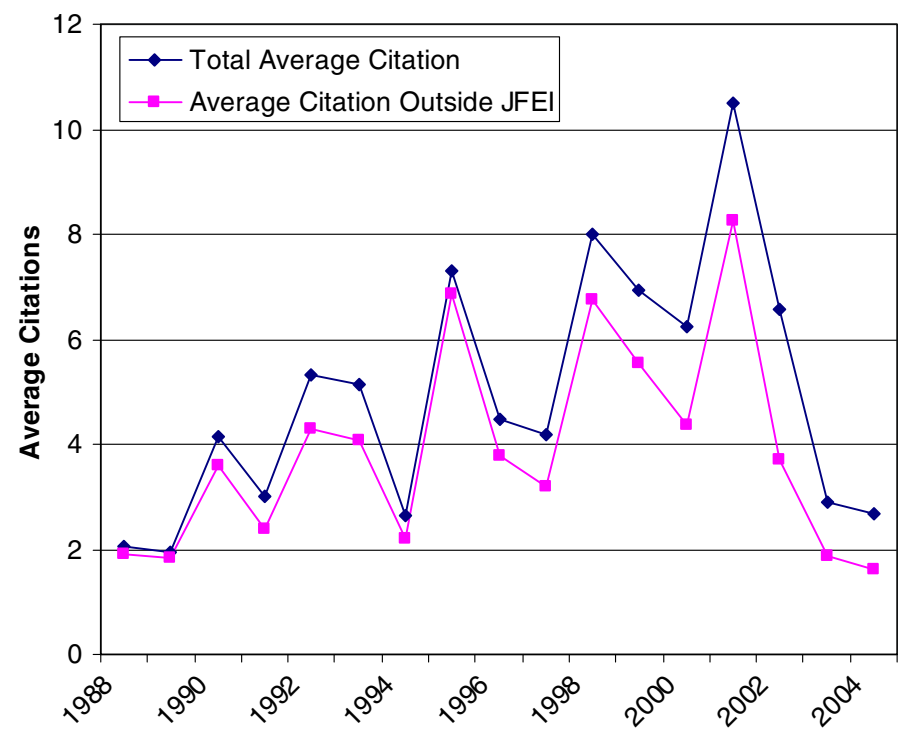

Fig. 3 Citation rates of the Journal of Family and Economic Issues

Another important citation indicator or JFEI's impact is average out-of-journal citation percentages. Figure 3 shows the trend for average out-of-journal citations. Not surprisingly, this trend tracks the overall average citation trend fairly closely. Some years had higher out-of-journal citations rates while other years had lower rates. For the period of 1988-2004, an average of $79 \%$ of citations of JFEI articles were made in journals other than JFEI.

The top 21 most cited papers in JFEI in 1988-2007 are presented in Table 2. Like JFEI studies in general, these papers tackled many different subjects; they were found in eight of the fifteen themes. Interestingly, though, thirteen of these top cited papers were from the categories of caregiving, employment and work-family issues, and family owned businesses. Multidisciplinary teams authored about half of the multi-authored papers in this highly cited group of studies.

\section{Conclusion}

JFEI has grown substantially in the 20 years since its predecessor adopted a focus on the association between families and economic issues. Most notably, JFEI has impacted research by providing an outlet where quality manuscripts on this relationship are published. The breadth and depth of the focus of the articles published on family/economic issues in JFEI is substantial. This is important because relatively few family studies journals publish many articles on family and economic issues. Scholars continue to cite $J F E I$ articles both in JFEI and outside the journal. As important social economic issues change and as families respond (e.g., the impending retirement of millions of baby boomers), it is hoped that scholars will continue to publish their work in JFEI. 
Table 2 The top 21 most frequently cited JFEI articles out of 420 articles published in 1988-2007

Number of Citations Paper

Tausig, M., \& Fenwick, R. (2001). Unbinding time: Alternate work schedules and work-life balance. Journal of Family and Economic Issues, 22, 101-119.

Bryant, W. K., \& Zick, C. D. (1996). Are we investing less in the next generation? Historical trends in time spent caring for children. Journal of Family and Economic Issues, 17, 365-392.

Yeung, W. J., \& Hofferth, S. L. (1998). Family adaptations to income and job loss in the U.S. Journal of Family and Economic Issues, 19, 255-283.

Moore, K. A., Morrison, D. R., \& Glei, D. A. (1995). Welfare and adolescent sex: The effects of family history, benefit levels, and community context. Journal of Family and Economic Issues, 16, 207-237.

Fast, J. E., Williamson, D. L., \& Keating, N. C. (1999). The hidden costs of informal elder care. Journal of Family and Economic Issues, 20, 301-325.

Roehling, P. V., Roehling, M. V., \& Moen, P. (2001). The relationship between work-life policies and practices and employee loyalty: A life course perspective. Journal of Family and Economic Issues, 22, 141-170.

Bowen, G. L. (1998). Effects of leader support in the work unit on the relationship between work spillover and family adaptation. Journal of Family and Economic Issues, 19, 25-52.

Beverly, S. G., McBride, A. M., \& Schreiner, M. (2003). A framework of assetaccumulation stages and strategies. Journal of Family and Economic Issues, 24, $143-156$.

Wheelock, J., \& Baines, S. (1998). Dependency or self-reliance? The contradictory case of work in UK small business families. Journal of Family and Economic Issues, 19, 53-73.

Hao, L. (1995). Poverty, public assistance, and children in intact and singlemother families. Journal of Family and Economic Issues, 16, 181-205.

Roxburgh, S. (2002). Racing through life: The distribution of time pressures by roles and role resources among full-time workers. Journal of Family and Economic Issues, 23, 121-145.

Stafford, K., Winter, M., Duncan, K. A., \& Genalo, M. A. (1992). Studying athome income generation: Issues and methods. Journal of Family and Economic Issues, 13, 139-158.

Abroms, L. C., \& Goldscheider, F. K. (2002). More work for mother: How spouses, cohabiting partners and relatives affect the hours mothers work. Journal of Family and Economic Issues, 23, 147-166.

Danes, S. M., Leictentritt, R. D., \& Metz, M. E., \& Huddleston-Casas, C. (2000). Effects of conflict styles and conflict severity on quality of life of men and women in family businesses. Journal of Family and Economic Issues, 21, 259286.

Nichols, L. S., \& Junk, V. W. (1997). The sandwich generation: Dependency, proximity, and task assistance needs of parents. Journal of Family and Economic Issues, 18, 299-326.

Heck, R. K. Z., Winter, M., \& Stafford, K. (1992). Managing work and family in home-based employment. Journal of Family and Economic Issues, 13, 187212.

Pepper, J. V. (1995). Dynamics of the intergenerational transmission of welfare receipt in the United States. Journal of Family and Economic Issues, 16, 265279.

Stewart, C. C., \& Danes, S. M. (2001). Inclusion and control in resort family businesses: A development approach to conflict. Journal of Family and Economic Issues, 22, 293-320. 
Table 2 continued

\begin{tabular}{|c|c|}
\hline Number of Citations & Paper \\
\hline 13 & $\begin{array}{l}\text { Afxentiou, D., \& Hawley, C. B. (1997). Explaining female teenagers' sexual } \\
\text { behavior and outcomes: A bivariate probit analysis with selectivity correction. } \\
\text { Journal of Family and Economic Issues, 18, 91-106. }\end{array}$ \\
\hline 13 & $\begin{array}{l}\text { Rowe, B. R., \& Bentley, M. T. (1992). The impact of the family on home-based } \\
\text { work. Journal of Family and Economic Issues, 13, 279-297. }\end{array}$ \\
\hline 13 & $\begin{array}{l}\text { Sumarwan, U., \& Hira, T. K. (1993). The effects of perceived locus of control and } \\
\text { perceived income adequacy on satisfaction with financial status of rural } \\
\text { households. Journal of Family and Economic Issues, 14, 343-364. }\end{array}$ \\
\hline
\end{tabular}

Source: Google Scholar, as of February 13, 2008

\section{Appendix: Annotated Bibliography}

Caregiving

\begin{tabular}{ll}
\hline Reference & Keywords \\
\hline
\end{tabular}

Dressel, T., \& Martin, M. (1989). Needs and preferences for employer supported child care: A feasibility study. Journal of Family and Economic Issues, 10, 163-171.

Prawitz, A. D., Lawrence, F. C., Draughn, P. S., \& Wozniak, P. J. (1994). Criteria families use to select nursing homes. Journal of Family and Economic Issues, 15, 37-51.

White-Means, S. I., \& Change, C. F. (1994). Informal caregivers' leisure time and stress. Journal of Family and Economic Issues, 15, 117-136.

Folk, K. F. (1994). For love or money: Costs of child care by relatives. Journal of Family and Economic Issues, 15, 243-260.

Bryant, W. K., \& Zick, C. D. (1996). Are we investing less in the next generation? Historical trends in time spent caring for children. Journal of Family and Economic Issues, 17, 365-392.

Nichols, L. S., \& Junk, V. W. (1997). The sandwich generation: Dependency, proximity, and task assistance needs of parents. Journal of Family and Economic Issues, 18, 299-326.

Joesch, J. M. (1998). Where are the children? Extent and determinants of preschooler's child care time. Journal of Family and Economic Issues, 19, 75-99.

Hunts, H. J. H., \& Avery, R. J. (1998). Relatives as child care givers: After hours support for nontraditional workers. Journal of Family and Economic Issues, 19, 315-341.
Child Care, Employee Benefits

Consumer Decision Making, Elderly Housing, Long-term Care, Nursing Home Placement

Informal Caregiving, Leisure Time, Long-term Care Economics, Stress

Child Care, Employment, Interhousehold Transfers

Human Capital Development, Parental Child Care, Time Use

Aging Parents, Caregiver, Dependency, Sandwich Generation, Task Assistance

Child Care, Time

Child Care, Low Income, Relatives, Nontraditional Work Schedules 
Appendix continued

Reference
Baydar, N., Greek, A., \& Gritz, R. M. (1999).
Young mothers' time spent at work and time
spent caring for children. Journal of Family
and Economic Issues, 20, 61-84.

Tam, V. C., W., and Rettig, K. D. (1999). Decision-making of mothers in Hong Kong regarding the occasional use of alternative child-care arrangements. Journal of Family and Economic Issues, 20, 149-162.

Davey, A., \& Patsios, D. (1999). Formal and informal community care to older adults: Comparative analysis of the United States and Great Britain. Journal of Family and Economic Issues, 20, 271-299.

Fast, J. E., Williamson, D. L., \& Keating, N. C. (1999). The hidden costs of informal elder care. Journal of Family and Economic Issues, 20, 301-325.

Avery, R. J., Haynes, D. C., \& Haynes, G. W. (2000). Managing work and family: The decision to outsource child care in families engaged in family-owned businesses. Journal of Family and Economic Issues, 21, 227-258.

Brandon, P. D. (2000). Child care utilization among workign mothers raising children with disabilities. Journal of Family and Economic Issues, 21, 343-364.

Caputo, R. K. (2002). Adult daughters as parental caregivers: Rational actors versus rational agents. Journal of Family and Economic Issues, 23, 27-50.

Delgadillo, L., Sorensen, S., \& Coster, D. C. (2004). An exploratory study of preparation for future care among older Latinos in Utah. Journal of Family and Economic Issues, 25, 51-78.

Wolfe, B., \& Scrivner, S. (2004). Child care use and parental desire to switch care type among a low-income population. Journal of Family and Economic Issues, 25, 139-162.

White-Means, S. I., \& Rubin, R. M. (2004). Trade-offs between formal home health care and informal family caregiving. Journal of Family and Economic Issues, 25, 335-358.

Press, J., \& Fagan, J. (2006). Spousal childcare involvement and perceived support for paid work. Journal of Family and Economic Issues, 27, 354-374.
Keywords

Child Care, Interactive Care, Physical Care, Time Use

Decision-making, Alternative Child Care, Grounded Theory, Hong Kong

Family Caregiving, Community-based Longterm Care, Gerontology, Cross-cultural, Unmet Need

Economic Costs, Eldercare, Informal Care, Non-economic Costs

Child Care, Family-owned Business, Household Management, Outsourcing Household Production

Child Care, Children with Disabilities, Maternal Labor Force Participation

Altruism, Caregiver Behavior, Inheritance, Public Transfer Programs, Rational Choice Theory

Aging, Care Planning, Filial Obligations, Knowledge of Services, Latinos

Center-based Care, Child Care,

Child Care Subsidy, Low-income Families

Caregivers, Family Care Giving, Health Policy, Home Health Care

Childcare, Family Work Conflict, Housework, Spouse Support 
Appendix continued

\begin{tabular}{lc}
\hline Reference & Keywords \\
\hline $\begin{array}{l}\text { Koh, S.-K., \& MacDonald, M. (2006). Financial } \\
\text { reciprocity and elder care: Interdependent }\end{array}$ & $\begin{array}{c}\text { Elder Care, Family Financial Transfers, } \\
\text { Mid-Life Adults }\end{array}$ \\
resource transfers. Journal of Family and & \\
Economic Issues, 27, 420-436. & \\
Shaber, P. L., \& Stum, M. S. (2007). Factors & Family Decision Making, Long-term Care \\
impacting group long-term care insurance & Insurance \\
enrollment decisions. Journal of Family and & \\
Economic Issues, 28, 189-205. & \\
Lai, D. W. L., \& Leonenko, W. (2007). Effects & Chinese Immigrants, Cost of Caregiving, Family \\
of caregiving on employment and economic & Caregiving, Financial Inadequacy \\
costs of chinese family caregivers in Canada. & \\
Journal of Family and Economic Issues, 28, & \\
411-427. & \\
Wilson, M. R., Van Houtven, C. H., Stearns, S. & Absenteeism, CESD, Depression, Informal \\
C., \& Clipp, E. C. (2007). Depression and & Care, Missing Work \\
missed work among informal caregivers of & \\
older individuals with dementia. Journal of & \\
Family and Economic Issues, 28, 684-698. & \\
\hline
\end{tabular}

Consumer Attitudes and Behaviors

\begin{tabular}{ll}
\hline Reference & Keywords \\
\hline $\begin{array}{c}\text { Abernathy, R. M., \& Abdel-Ghany, M. (1989). } \\
\text { Quality of goods and services as perceived by }\end{array}$ & $\begin{array}{l}\text { Elderly, Elderly Consumers, Ratings of Good and } \\
\text { Services, Young Consumers, Middle-Adulthood } \\
\text { the elderly and the young/middle-adulthood }\end{array}$ \\
Consumers
\end{tabular}
consumers. Journal of Family and Economic Issues, 10, 123-138.

Hawks, L. K., \& Ackerman, N. M. (1990). Family life cycle differences for shopping styles, information use, and decision-making. Journal of Family and Economic Issues, 11, 199-219.

Summers, T. A., Lawrence, F. C., Haynes, J. L., \& Wozniak, P. J. (1990). Perceived risk associated with apparel purchasing in discount stores. Journal of Family and Economic Issues, 11, 397-409.

Abdel-Ghany, M., \& Schwenk, F. N. (1993). Differences in consumption patterns in singleparent and two-parent families in the United States. Journal of Family and Economic Issues, 14, 299-315.

Douthitt, R. A., \& Huh, K. (1994). Expenditures on children by female-headed households. Journal of Family and Economic Issues, 15, 75-91.

Kivett, V. R., \& Schwenk, F. N. (1994). The consumer expenditures of elderly women: Racial, marital, and rural/urban impacts. Journal of Family and Economic Issues, 15, 261-277.

Consumer Choice, Consumption, Family Life Cycle

Apparel, Decision-Making, Discount Stores, Socioeconomic Risk

Consumption Expenditures, Consumption Patterns, Income Elasticities, Single-parent Families, Twoparent Families

Child-rearing Costs, Consumer Economics, Family Economics, Financial Management, Resource Management

Consumer Expenditures, Economic Well-being, Elderly, Older Women 
Appendix continued

\begin{tabular}{ll}
\hline Reference & Keywords \\
\hline $\begin{array}{l}\text { Fan, J. X., \& Chern, W. S. (1997). Analysis of } \\
\text { food consumption patterns in China: }\end{array}$ & China, Food Demand \\
Nonparametric and parametric approaches. & \\
Journal of Family and Economic Issues, 18, & \\
113-126. & \\
Moon, S.-J., \& Joung, S.-H. (1997). Expenditure & Economic Well-being, Expenditure Patterns, \\
patterns of divorced single-mother families & Household Production, Income Elasticities \\
and two-parent families in South Korea. & \\
Journal of Family and Economic Issues, 18, & \\
147-162. & \\
Zain, M. M., Aziz, N. A., Sanusi, Z. M., & \\
Mohamed, N., Ahmad, N., Jalil, N. A., & Consumer Expenditure, Manpower Planning, \\
Widdows, R., \& Yieh, K. (1997). Expenditure & \\
differences of university degree holders & \\
across occupational sectors in Malaysia. & \\
Journal of Family and Economic Issues, 18, \\
163-178.
\end{tabular}

Journal of Family and Economic Issues, 18, 211-224.

Meeks, C. B. (1998). Factors influencing adolscents' income and expenditures. Journal of Family and Economic Issues, 19, 131-150.

Sharpe, D. L., Abdel-Ghany, M., Kim, H-Y., \& Hong, G.-S. (2001). Alcohol consumption decisions in Korea. Journal of Family and Economic Issues, 22, 7-24.

Mauldin, T., Mimura, Y., \& Lino, M. (2001). Parental expenditures on children's education. Journal of Family and Economic Issues, 22, 221-241.

Fan, J. X., \& Abdel-Ghany, M. (2004). Patterns of spending behavior and the relative position in the income distribution: Some empirical evidence. Journal of Family and Economic Issues, 25, 163-178.

Lazaridis, P. (2004). Olive oil consumption in Greece: A microeconometric analysis. Journal of Family and Economic Issues, 25, 411-430.

Yin, X. (2005). New trends of leisure consumption in China. Journal of Family and Economic Issues, 26, 175-182.

Fan, J. X. \& Zick, C. D. (2006). Expenditure flows near widowhood. Journal of Family and Economic Issues, 27, 335-353.

Adolescents, Income, Earnings, Expenditures

Alcohol Consumption, Korea, Double-hurdle Model

Children's Education Expenditures, Primary and Secondary Educational Expenditure

Relative Income, Permanent Income, Consumer Expenditure, Budget Allocation

Demand System, Greece, Olive Oil, Survey Data

Culture Consumption, Entertainment, Leisure Consumption

Budget Allocation, Consumer Expenditure Survey, Expenditure Patttern, Widowhood 
Appendix continued

\begin{tabular}{ll}
\hline Reference & Keywords \\
\hline $\begin{array}{l}\text { Kim., H., Lee, J., \& Kim, D-K. (2006). The } \\
\text { impact of age and health on vehicle choices }\end{array}$ & $\begin{array}{c}\text { Age, Driving, Family Burden, Health, Vehicle } \\
\text { Types }\end{array}$ \\
among elders. Journal of Family and & \\
Economic Issues, 27, 437-457. & \\
Fontes, A., \& Fan, J. X., (2006). The effects of & Ethnicity, Compensatory Consumption, Status \\
ethnic identity on household budget allocation & Consumption, Budget Allocation \\
to status conveying goods. Journal of Family & \\
and Economic Issues, 27, 642-663. & \\
Dong, Q., \& Cao, X. (2006). The impact of & Chinese Adolescents, Media Exposure, Purchasing \\
American media exposure and self-esteem on & Involvement, Self-Esteem \\
$\begin{array}{l}\text { Chinese urban adolescent purchsing } \\
\text { involvement. Journal of Family and }\end{array}$ & \\
Economic Issues, 27, 664-674. & \\
Bakar, E. A., Masud, J., \& Jusho, Z. M. (2006). & College Students, Educational Loan, Malaysia \\
Knowledge, attitude and perceptions of & \\
University students towards educational & \\
loands in Malaysia. Journal of Family and \\
Economic Issues, 27, 692-701.
\end{tabular}

Contraception, Reproduction, and Sexual Behavior

\begin{tabular}{|c|c|}
\hline Reference & Keywords \\
\hline $\begin{array}{l}\text { Seiver, D. A., \& Cymrot, D. J. (1988). } \\
\text { Misperceptions of reproductive ideals among } \\
\text { American husbands and wives. Journal of } \\
\text { Family and Economic Issues, 9, 21-32. }\end{array}$ & None \\
\hline $\begin{array}{l}\text { Potter, A. E., \& Knaub, P. K. (1988). Single } \\
\text { motherhood by choice: A parenting } \\
\text { alternative. Journal of Family and Economic } \\
\text { Issues, 9, 240-249. }\end{array}$ & $\begin{array}{l}\text { Artificial Insemination, Family Policy Making, } \\
\text { Single Motherhood }\end{array}$ \\
\hline $\begin{array}{l}\text { Jurich, J. A., \& Huges, T. (1991). Predictors of } \\
\text { contraceptive use by adolescent mothers. } \\
\text { Journal of Family and Economic Issues, 12, } \\
\text { 7-21. }\end{array}$ & $\begin{array}{l}\text { Adolescent Pregnancy, Contraceptive Use, } \\
\text { Family Environment, Economic Wellbeing, } \\
\text { Future Orientation, Self-Esteem }\end{array}$ \\
\hline $\begin{array}{l}\text { Linn, R. (1991). Mature unwed mothers in } \\
\text { Israel: Socio-moral and psychological } \\
\text { dilemmas. Journal of Family and Economic } \\
\text { Issues, 12, 145-170. }\end{array}$ & $\begin{array}{l}\text { Childbearing, Decision-Making, Morality, } \\
\text { Motherhood, Single-Parents }\end{array}$ \\
\hline $\begin{array}{l}\text { Reschovsky, J., \& Gerner, J. (1991). } \\
\text { Contraceptive choice among teenagers: A } \\
\text { multivariate analysis. Journal of Family and } \\
\text { Economic Issues, 12, 171-194. }\end{array}$ & $\begin{array}{l}\text { Adolescents, Contraception, Decision Making, } \\
\text { Pregnancy, Sex Education }\end{array}$ \\
\hline $\begin{array}{l}\text { Kingsbury, N. M., \& Greenwood, L. (1992). } \\
\text { Fertility expectation and employment across } \\
\text { three female cohorts. Journal of Family and } \\
\text { Economic Issues, 13, 73-93. }\end{array}$ & $\begin{array}{l}\text { Baby Boomer, Employment, Female, Fertility, } \\
\text { Rearing Children }\end{array}$ \\
\hline
\end{tabular}


Appendix continued

\begin{tabular}{ll}
\hline Reference & Keywords \\
\hline $\begin{array}{l}\text { Krishnan, V. (1994). The effect of income on } \\
\text { fertility among Canadian women. Journal of }\end{array}$ & $\begin{array}{c}\text { Differential Fertility, Expected Income, } \\
\text { Immigrant Generation Relative Income }\end{array}$ \\
$\begin{array}{l}\text { Family and Economic Issues, 15, 23-36. } \\
\text { Moore, K. A., Morrison, D. R., \& Glei, D. A. }\end{array}$ & $\begin{array}{c}\text { Adolescents, Contraception, Sexual Behavior, } \\
\text { (1995). Welfare and adolescent sex: The }\end{array}$ \\
Teen, Welfare
\end{tabular}

effects of family history, benefit levels, and community context. Journal of Family and Economic Issues, 16, 207-237.

Afxentiou, D., \& Hawley, C. B. (1997). Explaining female teenagers' sexual behavior and outcomes: A bivariate probit analysis with selectivity correction. Journal of Family and Economic Issues, 18, 91-106.

Tomal, A. (1999). Parental involvement laws and minor and non-minor teen abortion and birth rates. Journal of Family and Economic Issues, 20, 149-162.

Jones, A. S., Astone, N. M., Keyl, P. M., Kim, Y. J., \& Alexander, C. S. (1999). Teen childbearing and educational attainment: A comparison of methods. Journal of Family and Economic Issues, 20, 387-418.

Gyima, S. O., White, J., \& Maxim, P. (2005). Cohort perspectives on women's educational attainment and the timing of parenthood in Ghana. Journal of Family and Economic Issues, 26, 123-142.

Huang, J.-T., Kao, A-P., \& Hung, W-C. (2006). The influence of college tuition and fees on fertility rates in Taiwan. Journal of Family and Economic Issues, 27, 626-642.

Medoff, M. H., (2007). Price, restrictions and abortion demand. Journal of Family and Economic Issues, 28, 583-599.

AFDC, Childbearing, Sexual Engagement, Socioeconomic Variables

Parental Involvement Laws, Teen Abortion Rates

Adolescent Fertility, Omitted Variables, Selection, Teen Pregnancy, Teenage Child Bearing

Age at First Birth, Ghana, Maternal Education, Sub-Saharan Africa, Timing of Parenthood

College Tuition and Fees, General Fertility Rate, Higher Education, Taiwan

Abortion Demand, Restrictive Abortion Laws

Division of Labor, Gender Roles, or Women's Labor Force Participation

\begin{tabular}{|c|c|}
\hline Reference & Keywords \\
\hline $\begin{array}{l}\text { Crockenberg, S. B. (1988). Stress and role } \\
\text { satisfaction experienced by employed and } \\
\text { nonemployed mothers with young children. } \\
\text { Journal of Family and Economic Issues, 9, } \\
\text { 97-110. }\end{array}$ & $\begin{array}{l}\text { Maternal Employment, Social Support, Role } \\
\text { Satisfaction, Stress, Unemployment }\end{array}$ \\
\hline $\begin{array}{l}\text { Makowsky, P. P., Cook, A. S., Berger, P. S., \& } \\
\text { Powell, J. (1988). Women's perceived stress } \\
\text { and well-being following voluntary and } \\
\text { involuntary relocation. Journal of Family and } \\
\text { Economic Issues, 9, 111-122. }\end{array}$ & $\begin{array}{l}\text { Geographic Mobility, Marital Satisfaction, } \\
\text { Stress, Relocation }\end{array}$ \\
\hline $\begin{array}{l}\text { Altergott, K. (1988). Work and family: } \\
\text { Understanding men's role evaluations. } \\
\text { Journal of Family and Economic Issues, 9, } \\
\text { 181-198. }\end{array}$ & $\begin{array}{l}\text { Employment, Family Roles, Fathers, Husbands, } \\
\text { Role Evaluations }\end{array}$ \\
\hline
\end{tabular}


Appendix continued

Reference
Folk, K. F., Nickols, S. Y., \& Peck, C. J. (1989).
Social-Psychological factors related to work
status of rural women. Journal of Family and
Economic Issues, 10, 325-343.

Gerner, J. L., Montalto, C. P., \& Bryant, W. K. (1990). Work patterns and marital status change. Journal of Family and Economic Issues, 11, 7-21.

Pritchard, M. E. (1990). The value of the second income to two-earner families with children. Journal of Family and Economic Issues, 11, 127-141.

Zick, C. D., \& Bryant, W. K. (1990). Shadow wage assessments of the value of home production: Patterns from the 1970's. Journal of Family and Economic Issues, 11, 143-160.

Forsyth, C. J., \& Gramling, R. (1990). Adaptive familial strategies among merchant seamen. Journal of Family and Economic Issues, 11, 183-198.

Key, R. (1990). Complementarity and substitutability in family members' time allocated to household producation activities. Journal of Family and Economic Issues, 11, 225-256.

Wozniak, P. J., \& Scholl, K. K. (1990). Employment motivations of farm spouses. Journal of Family and Economic Issues, 11, 321-342.

Ward, D. (1991). Uncounted care. Journal of Family and Economic Issues, 12, 77-87.

Godwin, D. D. (1991). Spouses' time allocation to household work: A review and critique. Journal of Family and Economic Issues, 12, 253-294.

Anderson, E. A. (1992). Decision-making style: Impact on satisfaction of the commuter couples' lifestyle. Journal of Family and Economic Issues, 13, 5-21.

McCullough, J., \& Zick, C. D. (1992). The roles of role strain, economic resources and time demands in explaining mothers' life satisfaction. Journal of Family and Economic Issues, 13, 23-44.

Hong, G. S., \& White-Means, S. I. (1993). Do working mothers have healthy children? JFEI, 14, 163-186.

Bryant, W. K., \& Zick, C. D. (1994). The economics of housespousery: An essay on household work. Journal of Family and Economic Issues, 15, 137-168.
Keywords

Gender Role Attitudes, Labor Force Participation, Psychological Needs, Rural Families

Divorce, Housework, Labor Supply, Remarriage

Dual-Earning Strategy, Income, Income Differences

Home Production, Income Distribution

Employment, Fathers Roles, Husbands Roles

Complementarity, Household Production, Substitutability, Time-Use

Farm Families, Off-farm Employment, Women's Labor Force Participation

Caregiving, Cost, Elder Care, Unpaid Work, Gender Roles

Household Division of Labor, Housework, Time Use

Commuter Marriage, Coping Strategies, Decision-making, Desirableness of Lifestyle, Life Satisfaction

Dual-earner, Full-time Homemakers, Life Satisfaction, Single-parent Mother

Children, Health Status, Maternal Employment, Mental Health

Household Work, Time Use, Value of Time 
Appendix continued

Reference
Olson, G. I., \& Xiao, J. J. (1996). Effects of
relative advantage on time use in farm
families. Journal of Family and Economic
Issues, 17, 351-363.

Campione, W. A., \& Jerrell, M. (1997). Determination of reentry wages of displaced homemakers. Journal of Family and Economic Issues, 18, 49-68.

Danes, S. M., \& McTavish, D. G. (1997). Role involvement of farm women. Journal of Family and Economic Issues, 18, 69-89.

Crowley, M. S. (1998). Men's self-perceived adequacy as the family breadwinner: Implications for their psychological, marital, and work-family well-being. Journal of Family and Economic Issues, 19, 7-23.

Biddlecom, A. E., \& Kramarow, E. A. (1998). Household headship among married women: The roles of economic power, education, and convention. Journal of Family and Economic Issues, 19, 367-382.

Monroe, P. A., Blalock, L. B., \& Vlosky, R. P. (1999). Work opportunities in a nontraditional setting for women exiting welfare: A case study. Journal of Family and Economic Issues, 20, 35-60.

Ciscel, D. H., Sharp, D. C., \& Heath, J. A. (2000). Family work trends and practices 1971-1999. Journal of Family and Economic Issues, 21, 23-36.

Mano-Negrin, R. \& Kirschenbaum, A. (2000). Spousal interdependence in turnover decisions: The case of Israel's medical sector employees. Journal of Family and Economic Issues, 21, 97-122.

Kolodinsky, J., \& Shirey, L. (2000). The impact of living with an elder parent on adult daughter's labor supply and hours of work. Journal of Family and Economic Issues, 21, 149-175.

Hundley, G. (2001). Domestic division of labor and self/organizationally employed differences in job attitudes and earning. Journal of Family and Economic Issues, 22, 121-139.

Forgays, D. K., Ottaway, S. A., Guarin, A., \& D’Alessio, M. (2001). Parenting stress in employed and at-home mothers in Italy. Journal of Family and Economic Issues, 22, 327-351.
Keywords

Division of Labor, Household Work, Specialization, Time Use

Displaced Homemakers, Reentrants, Wage Determination

Content Analysis, Farm Women, Role Involvement, Roles, Womens' Roles

Breadwinner Role, Earner Status, Family Men, Subjective Well-being

Household Headship, Marriage, United States Census

Family Policy, Female Labor Force Participation, Welfare Reform, Work Readiness

Family Labor, Gender

Turnover, Spouses’ Employment, Medical Professions

Co-residence, Female Labor Supply, Intergenerational Transfers

Self-employment, Family, Spillovers, Earnings, Job Satisfaction

Maternal Employment, Parenting Stress, Type A Behavior 
Appendix continued

Reference
Abroms, L. C., \& Goldscheider, F. K. (2002).
More work for mother: How spouses,
cohabiting partners and relatives affect the
hours mothers work. Journal of Family and
Economic Issues, 23, 147-166.

Tsang, L. L. W., Harvey, C. D. H., Duncan, K. A., \& Sommer, R. (2003). The effects of children, dual earner status, sex role traditionalism, and marital structure on happiness over time. Journal of Family and Economic Issues, 24, 5-26.

Cobb, L. A., Seery, B. L., \& McKinney, K. (2003). College students' perceptions of employment-based marital dyad types. Journal of Family and Economic Issues, 24, 203-224.

O'Hara, B. (2004). Do mothers work to support ailing husbands? JFEI, 25, 179-198.

Edwards, M. E. (2005). Occupational structure and the employment of American mothers of young children. Journal of Family and Economic Issues, 26, 31-53.

Urban, J. A., \& Olson, P. N. (2005). A comprehensive employment model for lowincome mothers. Journal of Family and Economic Issues, 26, 101-122.

Chan, K.-B., \& Wong, O. M. H. (2005). Introduction private and public: Gender, generation and family life in flux. Journal of Family and Economic Issues, 26, 447-464.

Lee, Y. G., Hong, G.-S., Rowe, B. R. (2006). Third shift women in business-owning families. Journal of Family and Economic Issues, 27, 72-91.

Takyi, B. K., \& Broughton, C. L. (2006). Marital Stability in Sub-Saharan Africa: Do women's autonomy and socioeconomic situation matter? Journal of Family and Economic Issues, 27, 113-132.

Stanfors, M. A. (2006). Labor force transitions after childbirth among five birth cohrots in Sweden. Journal of Family and Economic Issues, 27, 287-309.

Baydar, N., Joesch, J. M., Kieckhefer, G., Kim, H., \& Greek, A. (2007). Employment behaviors of mothers who have a child with asthma. Journal of Family and Economic Issues, 28, 337-355.

Estes, S. B., Noonan, M. C., \& Maume, D. J. (2007). Is work-family policy use related to the gendered division of housework? JFEI, $28,527-545$.
Keywords

Child Care, Cohabitation, Division of Labor, Living Situation, Maternal Employment

Children, Dual Earner Status, Marital Happiness, Marital Structure, Sex Role Traditionalism

Marital Dyads, Marital Satisfaction, Marital Stability, Perceptions, Power

Health, Spousal Labor Supply

Employment, Family, Mothers, Occupation, Work

Employment, Family Resource Management, Low-income, Mothers, Welfare Reform

Private and Public, Gender, Generation Politics

Family-Owned Businesses, Family Well-being, Married Women's Employment, Role Strain

Africa, Divorce, Ghana, Marital Instability, Women's Autonomy

Fertility Gender, Labor Force Transitions, Longitudinal Analysis, Part-time Work

Childhood Asthma, Chronic Conditions, Longitudinal Analysis, Maternal Employment

Family, Gender, Housework, Work 
Appendix continued

\begin{tabular}{ll}
\hline Reference & Keywords \\
\hline $\begin{array}{l}\text { Tomohara, A., \& Lee, H. J., (2007). Did state } \\
\text { children's health insurance program affect } \\
\text { married women's labor supply? JFEI, 28, }\end{array}$ \\
668-683.
\end{tabular}

Economic Issues and Family Relationships

\begin{tabular}{ll}
\hline Reference & Keywords \\
\hline
\end{tabular}

Wilhelm, M. S., \& Ridley, C. A. (1988).

Unemployment induced adaptations:

Relationships among economic responses and individual and marital well-being. Journal of Family and Economic Issues, 9, 5-20.

Zvonkovic, A. M. (1988). Underemployment: Individual and marital adjustment to income loss. Journal of Family and Economic Issues, 9, 161-178.

Berger, P. S., Powell, J., \& Cook, A. S. (1988). The relation of economic factors to perceived stress in mobile families. Journal of Family and Economic Issues, 9, 297-313.

Weigel, R. R. (1988). Coping with economic stress: Implications for helping professionals. Journal of Family and Economic Issues, 9, 367-382.

Johnson, P. J. (1989). Resources for coping with economic distress: The situation of unemployed Southeast Asian refugees.

Journal of Family and Economic Issues, 10, 18-43.

Marotz-Baden, R., \& Colvin, P. L. (1989). Adapatability, cohesion, and coping strategies of unemployed blue-collar families with adolescents. Journal of Family and Economic Issues, 10, 44-60.

Hira, T. K., Fansiow, A. M., \& Titus, P. M. (1989). Changes in financial status influencing level of satisfaction in households. Journal of Family and Economic Issues, 10, 107-121.

Voydanoff, P., \& Donnelly, B. W. (1989). Economic distress and mental health: The role of family coping resources and behaviors. Journal of Family and Economic Issues, 10, 139-162.

Dollahite, D. C. (1991). Family resource management and family stress theories: Toward a conceptual integration. Journal of Family and Economic Issues, 12, 361-377.

Hennon, C. B. (1992). Toward the turn of the century. Journal of Family and Economic Issues, 13, 355-372.
None

Income loss, Marital Satisfaction,

Underemployment, Depression

Control, Economic Well-being, Economic Satisfaction, Geographic Mobility, Relocation, Stress

Coping Strategies, Family Adaptation, Helping Professionals, Support Services

Canada, Refugees, Southeast Asia, Unemployment

Adaptability, Circumplex Model, Cohesion, Coping Strategies, Unemployment

Family Financial Status, Household Debt, Household assets, Satisfaction

Economic Distress, Coping Behaviors, Coping Resources, Mental Health, Stress

\section{Adaptation, Coping, Crisis, Family Resource} Management, Family Stress

Cubistic Family Studies, Socially Situated Actions, Sustainable Interaction, Symbolic Interaction, Vocabularies of Motive 
Appendix continued

\begin{tabular}{ll}
\hline Reference & Keywords \\
\hline
\end{tabular}

Cole, C. L. (1992). Interpersonal and economic resources and marital quality. Journal of Family and Economic Issues, 13, 421-433.

Coleman, M. \& Ganong, L. H. (1992). Financial responsibility for children following divorce and remarriage. Journal of Family and Economic Issues, 13, 445-455.

Dollahite, D. C., \& Rommel, J. I. (1993). Individual and relationship capital: Implications for theory and research on families. Journal of Family and Economic Issues, 14, 27-48

Hyun, E. M., Bauer, J. W., \& Hogan, M. J., (1993). Resource adequacy perception and marital satisfaction of rural wives and husbands: A nonrecursive model. Journal of Family and Economic Issues, 14, 215-236.

Pasley, K., Sandras, E., \& Edmondson, M. E. (1994). The effects of financial management strategies on quality of family life in remarriage. Journal of Family and Economic Issues, 15, 53-70.

Voydanoff, P., Fine, M. A., \& Donnelly, B. W. (1994). Family structure, family organization, and quality of family life. Journal of Family and Economic Issues, 15, 175-200.

Couch, K. A., \& Lillard, D. R. (1997). Divorce, educational attainment, and the earnings mobility of sons. Journal of Family and Economic Issues, 18, 231-245.

Rettig, K. D., Leichtentritt, R. D., \& Danes, S. M. (1999). The effects of resources, decision making, and decision implementing on perceived family well-being in adjusting to an economic stressor. Journal of Family and Economic Issues, 20, 5-34.

Jeynes, W. H. (2002). Examining the effects of parental absence on the academic achievement of adolescents: The challenge of controlling for family income. Journal of Family and Economic Issues, 23, 189-210.

Huang, J.-T. (2003). Unemployment and family behavior in Taiwan. Journal of Family and Economic Issues, 24, 27-48.

Johnson, P. J., (2003). Financial responsibility for the family: The case of southeast Asian refugees in Canada. Journal of Family and Economic Issues, 24, 121-142.
Marital Quality, Resources, Social Exchange

Child Support, Eivorce, Mediation, Remarriage

Economic Theory, Family Economics, Family Theory, Human Capital Theory

Marital Satisfaction, Money Management, Resource Adequacy Perception, Rural Husband and Wives

Financial Behavior, Financial Management, Remarriage, Satisfaction, Stepfamily

Family, Parents, Relationships, Stepfamilies, Work

Divorce, Educational Attainment, Intergenerational Earnings Correlations

Resources, Decision Making, Family Wellbeing, Economic Stressor, Farm Households

Academic Achievement, Death, Divorce, Education, Parental Absence

Conception, Divorce, Marriage, Taiwan, Unemployment

Financial Responsibility for Family, Immigrants, Individualism, Collectivism, Refugees, Vietnamese 
Appendix continued

Reference
Dennis, J. M., Parke, R. D., Coltrane, S. Blacher,
J., \& Borthwick-Duffy, S. A. (2003).
Economic pressure, maternal depression, and
child adjustment in Latino families: An
exploratory study. Journal of Family and
Economic Issues, 24, 183-202.
Baloush-Kleinman, V., \& Sharlin, S. A. (2004).
Social, economic, and attitudinal
characteristics of cohabitation in Israel.
Journal of Family and Economic Issues, 25,
255-269.
Light, A., \& Ureta, M. (2004). Living
arrangements, employment status, and the
economic well-being of Mothers: Evidence
from Brazil, Chile, and the U.S. Journal of
Family and Economic Issues, 25, 301-334.

Abbott, D. A., Sharma, S., \& Verma, S. (2004). The emotional environment of families experiencing chronic poverty in India. Journal of Family and Economic Issues, 25, 387-409.

Ornacka, K., \& Szczepaniak-Wiecha, I. (2005). The contemporary family in Poland: New trends and phenomena. Journal of Family and Economic Issues, 26, 195-224.

Tsun, A., O.-K., \& Lui-Tsang, P. S.-K. (2005). Violence against wives and children in Hong Kong. Journal of Family and Economic Issues, 26, 465-486.

Wong, O. M. H. (2005). The socioeconomic determinants of the age at first marriage among women in Hong Kong. Journal of Family and Economic Issues, 26, 529-550.

Burgess, S., Gardiner, K., \& Propper, C. (2006). School, family and county effects on adolescents' later life chances. Journal of Family and Economic Issues, 27, 155-184.

Van den Troost, A., Vermulst, A. A., Gerris, J. R. R., Matthijs, K., \& Welkenhuysen-Gybels, J. (2006). Effects of spousal economic and cultural factors on Dutch marital satisfaction. Journal of Family and Economic Issues, 27, 235-262.

Arends-Kuenning, M., \& Duryea, S. (2006). The effect of parental presence, parents' education, and household headship on adolescents' schooling and work in Latin America. Journal of Family and Economic Issues, 27, 263-286.

Snyder, A. R., \& McLaughlin, D. K. (2006). Economic well-being and cohabitation: Another nonmetro disadvantage? Journal of Family and Economic Issues, 27, 562-582.
Keywords

Child Adjustment, Economic Pressure, Emotional Support, Latino Families, Maternal Depression

Cohabitation, Israel, Young Adults, Economic Characterisitcs

Household Income, Living Arrangements, Marital Status, Maternal Employment, Quantile Regression

Families and Poverty, Family Economics, Family Stress Theory, India, Poor Families

Economic Transitions, Economic Transformation, European Union, Families, Poland

Double Victimization, Ecological Perspective, Prevention, Violence to Women and Children

Age at First Marriage, Hazard Analysis, Hong Kong, Socioeconomic Determinants

Adolescence, Adult Income, Area Effects, Family Effects

Economic Theory of Marriage, Familialism, Female Employment, Marital Satisfaction, Sex Role Traditionalism

Child Labor, Education, Female-Headship, Latin America, Single Parents

Cohbitation, Economic well-being, Nonmetro Families 
Appendix continued

\begin{tabular}{|c|c|}
\hline Reference & Keywords \\
\hline $\begin{array}{l}\text { Chang, Y., \& Lee, K. Y. (2006). Household debt } \\
\text { and marital instability: Evidence from the } \\
\text { Korean Labor and Income Panel Study. } \\
\text { Journal of Family and Economic Issues, 27, } \\
\text { 675-691. }\end{array}$ & $\begin{array}{l}\text { Divorce, Financial Strain, Household Debt, } \\
\text { Korean Families }\end{array}$ \\
\hline $\begin{array}{l}\text { Dew, J. (2007). Two sides of the same coin? The } \\
\text { differing roles of assets and consumer debt in } \\
\text { marriage. Journal of Family and Economic } \\
\text { Issues, 28, 89-104. }\end{array}$ & Assets, Conflict, Debts, Marriage, Satisfaction \\
\hline $\begin{array}{l}\text { Xie, X., Xia, Y., \& Liu. X. (2007). Family } \\
\text { income and attitudes toward older people in } \\
\text { China: Comparison of two age cohorts. } \\
\text { Journal of Family and Economic Issues, 28, } \\
\text { 171-182. }\end{array}$ & $\begin{array}{l}\text { Attitudes Toward Older People, Baby Boomers, } \\
\text { College Students, Income, People's Republic } \\
\text { of China }\end{array}$ \\
\hline $\begin{array}{l}\text { Gudmunson, C. G., Beutler, I. F., Israelsen, C. } \\
\text { L., McCoy, J. K., \& Hill, E. J. (2007). Linking } \\
\text { financial strain to marital instability: } \\
\text { Examining the roles of emotional distress and } \\
\text { marital interaction. Journal of Family and } \\
\text { Economic Issues, 28, 357-376. }\end{array}$ & $\begin{array}{l}\text { Couple Interaction, Disagreements, Financial } \\
\text { Strain, Marital Conflict, Marital Instability }\end{array}$ \\
\hline $\begin{array}{l}\text { Parks-Yancy, R., DiTomaso, N., \& Post, C. } \\
\text { (2007). The mitigating effects of social and } \\
\text { financial capital resources on hardships. } \\
\text { Journal of Family and Economic Issues, 28, } \\
\text { 429-448. }\end{array}$ & Class, Hardships, Social Capital \\
\hline $\begin{array}{l}\text { Tiffin, P. A., Pearce, M., Kaplan, C., Fundudis, } \\
\text { T., \& parker, L. (2007). The impact of socio- } \\
\text { economic status and mobility on perceived } \\
\text { family functioning. Journal of Family and } \\
\text { Economic Issues, 28, 653-667. }\end{array}$ & $\begin{array}{l}\text { Family Functioning, Gender, Social Mobility, } \\
\text { Socio-economic Status }\end{array}$ \\
\hline
\end{tabular}

Employment and Work Family Issues

\begin{tabular}{lc}
\hline Reference & Keywords \\
\hline $\begin{array}{l}\text { Ridley, C. A., \& Wilhelm, M. S. (1988). } \\
\text { Adaptation to unemployment: Effects of a } \\
\text { mine closure on husbands and wives. Journal }\end{array}$ & $\begin{array}{c}\text { Unemployment, Depression, Economic } \\
\text { Satisfaction, Marital Satisfaction }\end{array}$ \\
of Family and Economic Issues, 9, 145-160. & \\
Smith, S. D., \& Price, S. J. (1992). Women and & Job Training, Rural, Unemployment, Women, \\
plant closings: Unemployment, & Work \\
reemployment, and job training enrollment & \\
following dislocation. Journal of Family and & \\
Economic Issues, 13, 45-72. & \\
Bowman, J. L. B., Couchman, G. M., \& Cole, S. & Displaced Workers, Human Capital, Midlife, \\
W. (1994). Midlife and older displaced & New Earnings, Older Workers \\
workers: A comparison of prediscplacement & \\
and new earnings. Journal of Family and & \\
Economic Issues, 15, 93-115. & \\
\hline
\end{tabular}


Appendix continued

\begin{tabular}{|c|c|}
\hline Reference & Keywords \\
\hline $\begin{array}{l}\text { Berger, P. S., Cook, A. S., DelCampo, R. L., } \\
\text { Herrera, R. S., \& Weigel, R. R. (1994). } \\
\text { Family/work roles' relation to perceived } \\
\text { stress: Do gender and ethnicity matter? } \\
\text { Journal of Family and Economic Issues, 15, } \\
\text { 223-242. }\end{array}$ & $\begin{array}{l}\text { Dual-income Families, Overload, Stress, Work/ } \\
\text { family Roles }\end{array}$ \\
\hline $\begin{array}{l}\text { Abdel-Ghany, M., \& Sharpe, D. L. (1994). } \\
\text { Racial wage differentials among young } \\
\text { adults: Evidence from the 1990s. Journal of } \\
\text { Family and Economic Issues, 15, 279-294. }\end{array}$ & $\begin{array}{l}\text { Black-White Wage Differentials, Labor Market } \\
\text { Discrimination, Sample-selection Bias, Wage } \\
\text { Structure }\end{array}$ \\
\hline $\begin{array}{l}\text { MacDermid, S. M., \& Targ, D. B. (1995). A call } \\
\text { for greater attention to the role of employers } \\
\text { in developing, transforming, and } \\
\text { implementing family policies. Journal of } \\
\text { Family and Economic Issues, 16, 145-170. }\end{array}$ & $\begin{array}{l}\text { Employers, Policy, Poverty, Wages, Work- } \\
\text { family }\end{array}$ \\
\hline $\begin{array}{l}\text { VandenHeuvel, A. (1997). Absence because of } \\
\text { family responsibilities: An examiniation of } \\
\text { explanatory factors. Journal of Family and } \\
\text { Economic Issues, 18, 273-297. }\end{array}$ & $\begin{array}{l}\text { Absenteeism, Child Care, Family } \\
\text { Responsibilities, Job Satisfaction Work-place } \\
\text { Flexibility }\end{array}$ \\
\hline $\begin{array}{l}\text { Bowen, G. L. (1998). Effects of leader support } \\
\text { in the work unit on the relationship between } \\
\text { work spillover and family adaptation. Journal } \\
\text { of Family and Economic Issues, 19, 25-52. }\end{array}$ & $\begin{array}{l}\text { Work and Family, Family Adaptation, } \\
\text { Workplace Supports, Military Families, } \\
\text { Social Supports }\end{array}$ \\
\hline $\begin{array}{l}\text { Firestone, J. M., Harris, R. J., \& Lamber, L. C. } \\
\text { (1999). Gender role ideology and the gender } \\
\text { based differences in earnings. Journal of } \\
\text { Family and Economic Issues, 20, 191-215. }\end{array}$ & Earnings, Gender, Gender Role, Socialization \\
\hline $\begin{array}{l}\text { Perry-Jenkins, M., \& Gillman, S. (2000), } \\
\text { Parental job experiences and children's well- } \\
\text { bing: The case of two-parent and single- } \\
\text { mother working-class families. Journal of } \\
\text { Family and Economic Issues, 21, 123-147. }\end{array}$ & $\begin{array}{l}\text { Working Class, Dual Earner, Single Mother, } \\
\text { Work-family, Children }\end{array}$ \\
\hline $\begin{array}{l}\text { Caputo, R. K. (2000). Race and marital history } \\
\text { as correlates of women's access to family- } \\
\text { friendly employee benefits. Journal of Family } \\
\text { and Economic Issues, } 21,365-385 \text {. }\end{array}$ & $\begin{array}{l}\text { Employee Benefits, Marriage, Race, Workplace } \\
\text { Issues, Women }\end{array}$ \\
\hline $\begin{array}{l}\text { Tausig, M., \& Fenwick, R. (2001). Unbinding } \\
\text { time: Alternate work schedules and work-life } \\
\text { balance. Journal of Family and Economic } \\
\text { Issues, 22, 101-119. }\end{array}$ & Work-life Balance, Work Schedules, Control \\
\hline $\begin{array}{l}\text { Roehling, P. V., Roehling, M. V., \& Moen, P. } \\
\text { (2001). The relationship between work-life } \\
\text { policies and practices and employee loyalty: } \\
\text { A life course perspective. Journal of Family } \\
\text { and Economic Issues, 22, 141-170. }\end{array}$ & Loyalty, Support, Benefits, Life Stage \\
\hline $\begin{array}{l}\text { Maume, D. J., \& Houston, P. (2001). Job } \\
\text { segregation differences in work-family } \\
\text { spillover among white-collar workers. } \\
\text { Journal of Family and Economic Issues, 22, } \\
\text { 171-189. }\end{array}$ & $\begin{array}{l}\text { Work-family Conflict, Job Segregation, } \\
\text { Tokenism, Face Time, Gender }\end{array}$ \\
\hline
\end{tabular}


Appendix continued

\begin{tabular}{l} 
Reference \\
\hline MacDermid, S. M., Hertzong, J. L., Kensign \\
K. B., \& Zipp, J. F. (2001). The role of \\
organizational size and industry in job quality \\
and work-family relationships. Journal of \\
Family and Economic Issues, 22, 191-216. \\
Leppel, K., Williams, M. L., \& Waldauer, C. \\
(2001). The impact of parental occupation a \\
socioeconomic status on choice of college \\
major. Journal of Family and Economic \\
Issues, 22, 373-394. \\
Jones, A. S. (2002). Wage and non-wage \\
compensation among young alcoholic and \\
heavy drinking women: A preliminary \\
analysis. Journal of Family and Economic \\
Issues, 23, 3-25.
\end{tabular}

Sharpe, D. L., Hermsen, J. M., \& Billings, J. (2002). Factors with having flextime: A focus on married workers. Journal of Family and Economic Issues, 23, 51-72.

Anderson, D. M., Morgan, B. L., \& Wilson, J. B. (2002). Perceptions of family-friendly policies: University versus corporate employees. Journal of Family and Economic Issues, 23, 73-92.

Flouri, E., \& Buchanan, A. (2002). Childhood predictors of labor force participation in adult life. Journal of Family and Economic Issues, 23, 101-120.

Carlson, D. S., Derr, C. B., \& Wadsworth, L. L. (2003). The effects of internal career orientation on multiple dimensions of workfamily conflict. Journal of Family and Economic Issues, 24, 99-116.

Elliott, M. (2003). Work and family role strain among University employees. Journal of Family and Economic Issues, 24, 157-181.

Voydanoff, P. (2004). The effects of work and community resources and demands on family integration. Journal of Family and Economic Issues, 25, 7-23.

Huang, Y.-H., Hammer, L. B., Neal, M. B., \& Perrin, N. A. (2004). The relationship between work-to-family conflict and familyto-work conflict: A longitudinal study.

Journal of Family and Economic Issues, 25, 79-100.

Hill, E. J., Martinson, V. K., Ferris, M. \& Baker, R. Z. (2004). Beyond the mommy track: The influence of new-concept part-time work for professional women on work and family. Journal of Family and Economic Issues, 25, 121-136.
Keywords

Family-friendly, Organizational Size, Small Businesses, Work-family Conflict,

Work-family Relationships

College Major, Parental Occupation, Socioeconomics

Alcohol, Compensation, Drinking, Employment, Women

Flextime, Married Workers

Family-friendly Policy, Higher Education, Perceptions, Work-life Programs

Father Involvement, Labor Force Participation, Mother Involvement, Unemployment

Career Dynamics, Career Orientation, Work and Family, Work-family Conflict

Family, Gender, Strain, University, Work

Community Participation, Economic Strain, Family Integration, Paid Work Hours, Resources, Demands

Longitudinal Research, Work-Family Conflict

Job Flexibility, Part-time Work, Professional Women, Work-family, Work/life 
Appendix continued

\begin{tabular}{ll}
\hline Reference & Keywords \\
\hline $\begin{array}{l}\text { Swanberg, J. E., (2005). Job-family role strain } \\
\text { among low-wage workers. Journal of Family } \\
\text { and Economic Issues, 26, 143-158. }\end{array}$ & Low-wage Workers, Role Strain, Work-family \\
$\begin{array}{l}\text { Dilworth, J. E. L., \& Kingsbury, N. (2005). } \\
\text { Home-to-job spillover for Generation X, }\end{array}$ & Baby Boomers, Role Conflict, Work-family \\
$\begin{array}{l}\text { Boomers, and Matures: A comparison. } \\
\text { Journal of Family and Economic Issues, 26, }\end{array}$ & Balance, Spillover \\
$\begin{array}{l}\text { 267-281. } \\
\text { Voydanoff, P. (2005). The differential salience } \\
\text { of family and community demands and } \\
\text { resources for family-to-work conflict and } \\
\text { facilitation. Journal of Family and Economic }\end{array}$ & $\begin{array}{c} \\
\text { Community Demands and Resources, Family }\end{array}$ \\
Demands, Family Resources, Family-to-Work \\
Conflict, Family-to-Work Facilitation
\end{tabular}
facilitation. Journal of Family and Economic Issues, 26, 395-417.

Christie-Mizell, C. A. (2006). The effects of traditional family and gender ideology on earnings: Race and gender differences. Journal of Family and Economic Issues, 27, 48-71.

Delgado, E. A., \& Canabal, M. E. (2006). Factors associated with negative spillover from job to home among Latinos in the United States. Journal of Family and Economic Issues, 27, 92-112.

Haddock, S. A., Zimmerman, T. S., Lyness, K. P., \& Ziemba, S. J. (2006). Practices of dual earner couples successfully balancing work and family. Journal of Family and Economic Issues, 27, 207-234.

Damiano-Teixeira, K. M. (2006). Managing conflicting roles: A qualitative study with female faculty members. Journal of Family and Economic Issues, 27, 310-334.

Kim, J., Sorhaindo, B., \& Garman, E. T. (2006). Relationship between financial stress and workplace absenteeism of credit counseling clients. JEFI, 27, 459-478.

Comer, D. R., \& Stites-Doe, S. (2006). Antecedents and consequences of faculty women's academic-parenting role balancing. Journal of Family and Economic Issues, 27, 495-512.

Sharpe, D. L., \& Abdel-Ghany, M. (2006). Determinants of income differentials: Comparing Asians with Whites and Blacks. Journal of Family and Economic Issues, 27, 588-600.

Craig, L. (2007). How employed mothers in Australia find time for both market work and childcare. Journal of Family and Economic Issues, 28, 69-87.

Earnings, Family Roles, Gender Ideology, Race

Latinos, Spillover, Work and Life

Couples, Dual-earner, Opportunity Costs, Tradeoffs, Work-family Balance

Employment-Family Interface, Qualitative Study, Women in Academia

Credit Counseling, Financial Education, Financial Stress, Personal Finance, Work Absenteeism

Academia, Interrole Conflict, Interrole Facilitation, Parenting, Role Balancing

Asians, Income Differentials

Childcare, Gender, Non-parental Care, Time Use, Work-Family Balance 
Appendix continued

\begin{tabular}{|c|c|}
\hline Reference & Keywords \\
\hline $\begin{array}{l}\text { Huang, J.-T. (2007). Labor force participation } \\
\text { and juvenile delinquency in Taiwan: A time } \\
\text { series analysis. Journal of Family and } \\
\text { Economic Issues, 28, 137-150. }\end{array}$ & $\begin{array}{l}\text { Juvenile Delinquency, Labor Force } \\
\text { Participation, Taiwan, Youth Crime }\end{array}$ \\
\hline $\begin{array}{l}\text { Swain, L. L., \& Garasky, S. (2007). Migration } \\
\text { decisions of dual-earner families: An } \\
\text { application of multilevel modeling. Journal of } \\
\text { Family and Economic Issues, 28, 151-170. }\end{array}$ & $\begin{array}{l}\text { Dual-Earner Families, Internal Migration, } \\
\text { Migration, Multilevel Modeling, Panel Study } \\
\text { of Income Dynamics }\end{array}$ \\
\hline $\begin{array}{l}\text { Perrucci, MacDermid, S., King, E., Tang, C-Y., } \\
\text { Brimeyer, T., Ramadoss, K., Kiser, S. J., \& } \\
\text { Swanberg, J. (2007). The signficance of shift } \\
\text { work: Current status and future directions. } \\
\text { Journal of Family and Economic Issues, 28, } \\
\text { 600-617. }\end{array}$ & $\begin{array}{l}\text { Family Life, Mental Health, Physical Health, } \\
\text { Shift Work }\end{array}$ \\
\hline
\end{tabular}

Family-Owned Businesses or Home Based Employment

\begin{tabular}{|c|c|}
\hline Reference & Keywords \\
\hline $\begin{array}{l}\text { Heck, R. K. Z. (1991). Employment location } \\
\text { choices: Factors associated with the } \\
\text { likelihood of homebased employment. } \\
\text { Journal of Family and Economic Issues, 12, } \\
\text { 217-233. }\end{array}$ & $\begin{array}{l}\text { Homebased employment, Homesteading, } \\
\text { Telecommuting, Work Location, } \\
\text { Working at Home }\end{array}$ \\
\hline $\begin{array}{l}\text { Owen, A. J., Carsky, M. L., \& Dolan, E. M. } \\
\text { (1992). Home-based employment: Historical } \\
\text { and current considerations. Journal of Family } \\
\text { and Economic Issues, 13, 121-138. }\end{array}$ & $\begin{array}{l}\text { Family Resource Management, Home-based } \\
\text { Business, Women's Employment, } \\
\text { Work and Family, Working at Home }\end{array}$ \\
\hline $\begin{array}{l}\text { Stafford, K., Winter, M., Duncan, K. A., \& } \\
\text { Genalo, M. A. (1992). Studying at-home } \\
\text { income generation: Issues and methods. } \\
\text { Journal of Family and Economic Issues, 13, } \\
\text { 139-158 }\end{array}$ & $\begin{array}{l}\text { At-home Income Generation, Home-based } \\
\text { Business, Home-based work, Research } \\
\text { Methods }\end{array}$ \\
\hline $\begin{array}{l}\text { Rowe, B. R., Stafford, K., \& Owen, A. J. (1992). } \\
\text { Who's working at home: The types of } \\
\text { families engaged in home-based work. } \\
\text { Journal of Family and Economic Issues, 13, } \\
\text { 159-172. }\end{array}$ & $\begin{array}{l}\text { Home-based Employment, Home Work, } \\
\text { Work and Family, Working at Home }\end{array}$ \\
\hline $\begin{array}{l}\text { Loker, S., \& Scannell, E. (1992). Characterisitcs } \\
\text { and practices of home-based workers. Journal } \\
\text { of Family and Economic Issues, 13, 172-186. }\end{array}$ & $\begin{array}{l}\text { Cluster Analysis, Home-based Worker, } \\
\text { Working at Home }\end{array}$ \\
\hline $\begin{array}{l}\text { Heck, R. K. Z., Winter, M., \& Stafford, K. } \\
\text { (1992). Managing work and family in home- } \\
\text { based employment. Journal of Family and } \\
\text { Economic Issues, 13, 187-212. }\end{array}$ & $\begin{array}{l}\text { Decision-making, Family Management, } \\
\text { Home-based Employment, Homesteading, } \\
\text { Working at Home }\end{array}$ \\
\hline $\begin{array}{l}\text { Heck, R. K. Z., Stafford, K., Howe, B., \& Owen, } \\
\text { A. J. (1992). The utilization of child care by } \\
\text { households engaged in home-based } \\
\text { employment. Journal of Family and } \\
\text { Economic Issues, 13, 213-237. }\end{array}$ & $\begin{array}{l}\text { Child Care, Home-based Employment, } \\
\text { Homesteading, Work Location, } \\
\text { Working at Home }\end{array}$ \\
\hline
\end{tabular}


Appendix continued

Reference
Masuo, D. M., Walker, R., \& Furry, M. M.
(1992). Home-based workers: Worker and
work characteristics. Journal of Family and
Economic Issues, 13, 245-262.

Loker, S., \& Scannell, E. (1992). The unique nature of textile and craft home-based workers: A comparison. Journal of Family and Economic Issues, 13, 263-277.

Rowe, B. R., \& Bentley, M. T. (1992). The impact of the family on home-based work. Journal of Family and Economic Issues, 13, 279-297.

Owen, A. J., Rowe, B. R., \& Gritzmacher, J. E. (1992). Building family functioning scales into the study of at-home income generation. Journal of Family and Economic Issues, 13, 299-313.

Heck, R. K. Z. (1992). The effects of children on the major dimensions of home-based employment. Journal of Family and Economic Issues, 13, 315-346.

Winter, M., Puspitawati, H., Heck, R. K. Z., \& Stafford, K. (1993). Time-management strategies used by households with homebased work. Journal of Family and Economic Issues, 14, 69-92.

Gritzmacher, J. E. (1993). Satisfaction with home-based employment. Journal of Family and Economic Issues, 14, 145-161.

Weigel, D. J., \& Ballard-Reisch, D. S. (1997). Merging family and firm: An integrated systems approach to process and change. Journal of Family and Economic Issues, 18, 7-31.

Wheelock, J., \& Baines, S. (1998). Dependency or self-reliance? The contradictory case of work in UK small business families. Journal of Family and Economic Issues, 19, 53-73.

Hennon, C. B., Jones, A., Roth, M., \& Popescu, L. (1998). Family-enterprise initiatives as a response to socioeconomic and polictal change in Eastern and Central Europe. Journal of Family and Economic Issues, 19, 235-253.

Haynes, G. W., Rowe, B. R., Walker, R. \& Hong, G.-S. (2000). The differences in financial structure between women- and menowned family businesses. Journal of Family and Economic Issues, 21, 209-226.
Keywords

Home-based Employment, Working at Home

Female Home-based Workers, Textile and Craft Home-based Workers

Cottage Industry, Home-based Work, Work and Family, Working at Home

Family Affective Behavior, Family Resource Management, Home-Based Business

Children and Employment, Home-based Employment, Homesteading, Working at home, Work Location

Adjustment Strategies, Coping Strategies, Home-based Work, Time Management

Home-based Businesses, Home-based Employment, Income Satisfaction, Life Satisfaction

Commitment, Family Business, Family Interaction, Family Satisfaction, Negotiation

Culture, Enterprise, Family Business, Small Business, Work Strategies

Family Business, Family Enterprise, Familybusiness Incubators, Businesses in Eastern and Central Europe

Family Businesses, Women Entrepreneurs, Financing Business Ventures 
Appendix continued

\begin{tabular}{l} 
Reference \\
\hline Danes, S. M., Leictentritt, R. D., \& Metz, \\
M. E., \& Huddleston-Casas, C. (2000). \\
Effects of conflict styles and conflict severity \\
on quality of life of men and women in family \\
businesses. Journal of Family and Economic \\
Issues, 21, 259-286. \\
Masuo, D., Fong, G., Yanagid, J., \& Cabal, \\
C. (2001). Factors associated with business \\
and family success: A comparison of single \\
manager and dual manager family business \\
households. Journal of Family and Economic \\
Issues, 22, 55-73.
\end{tabular}

Fitzgerald, M. A., \& Winter, M. (2001). The intrusiveness of home-based work on family life. Journal of Family and Economic Issues, 22, 75-92.

Fitzgerald, M. A., Winter, M., Miller, N. J. \& Paul, J. (2001). Adjustment strategies in the family business: Implications of gender and management role. Journal of Family and Economic Issues, 22, 265-291.

Stewart, C. C., \& Danes, S. M. (2001). Inclusion and control in resort family businesses: A development approach to conflict. Journal of Family and Economic Issues, 22, 293-320.

Kim., J., Zepeda, L., \& Kantor, P. (2005). Child labor supply on US family farms: An interdisciplinary conceptualization. Journal of Family and Economic Issues, 26, 159-173.

Amarapurkar, S. S., \& Danes, S. M. (2005). Farm business-owning couples: Interrelationships among business tensions, relationship conflict quality, and spousal satisfaction. Journal of Family and Economic Issues, 26, 419-441.

Zody, Z., Sprenkle, D., MacDermid, S., \& Schrank, H. (2006). Boundaries and the functioning of family and business systems. Journal of Family and Economic Issues, 27, 185-206.

Lee, Y. G., Danes, S. M., \& Shelley, M. C., (2006). Work roles, management and percieved well-being for married women within family businesses. Journal of Family and Economic Issues, 27, 523-541.

Haynes, G. W., Onochie, J. I., \& Muske, G. (2007). Is what's good for the business, good for the family: A financial assessment. Journal of Family and Economic Issues, 28, 395-409.
Keywords

Conflict, Conflict Style, Family Business, Quality of Life

Business Success, Family Business, Family Success

Home-based Work, Intrusiveness

Adjustment Strategies, Family Business, Gender

Business Conflict, Family Conflict, Family Business, FIRO, Resort Couples

Child Labor, Farm Labor, Household Bargaining

Family Business, Farm Couples, FIRO, Relationship Conflict, Spousal Satisfaction

Boundaries, Disengagement, Enmeshment, Family Business, Spill Over

Family Business, Family Management, Percieved Well-being

Business, Family, Financial, Success 
Appendix continued

\begin{tabular}{ll}
\hline Reference & Keywords \\
\hline $\begin{array}{l}\text { Philbrick, C. A., \& Fitzgerald, M. A., (2007). } \\
\text { Women in business-owning families: A }\end{array}$ & Family Business, Family Functioning, Women \\
comparison of roles, responsibilities and & \\
predicotrs of family functionality. Journal of & \\
Family and Economic Issues, 28, 618-634. & \\
\hline
\end{tabular}

Family Policy

\begin{tabular}{lc}
\hline Reference & Keywords \\
\hline Ritzdorf, M. (1988). Not in my neighborhood: & Alterative Family Forms, Family Definition, \\
Alternative lifestyles and municipal family & Housing, Zoning Ordinances \\
definitions. Journal of Family and Economic & \\
Issues, 9, 264-276. & \\
Rowe, B. R. (1989). Child support guidelines: & Child Support, Divorce, Family Policy, \\
Economic theory and policy considerations. & Support Guidelines \\
Journal of Family and Economic Issues, 10, & \\
345-369. & Child Support, Divorce, Divorce Settlement, \\
Stafford, K., Jackson, G., \& Seiling, S. (1990). & Support Guidelines \\
The effects of child support guidelines: An & \\
analysis of the evidence in court records. & \\
Journal of Family and Economic Issues, 11, & \\
361-381. & Diagnosis-related Groups, Family Caregivers, \\
Wisendsale, S. K., \& Waldron, R. J. (1991). & Family Impact Statement, Family Policy \\
Applying the family impact statement to & \\
DRGs: &
\end{tabular}

DRGs: Implications for future policymaking. Journal of Family and Economic Issues, 12, 89-102.

Morgan, L. A., Kitson, G. C. \& Kitson, J. T. (1992). The economic fallout from divorce: Issues for the 1990s. Journal of Family and Economic Issues, 13, 435-443.

Bowen, G. L., \& Neenan, P. A. (1993). Child day care and the employment of AFDC recipients with preschool children. Journal of Family and Economic Issues, 14, 49-68.

Waddoups, J. (1994). Open adoption, human capital formation, and uncertainty. Journal of Family and Economic Issues, 15, 5-21.

Hill, M. S. (1995). When is a family a family? Evidence from survey data and implications for family policy. Journal of Family and Economic Issues, 16, 35-64.

Anderson, E. A., \& Skinner, D. A. (1995). The components of family policy education. Journal of Family and Economic Issues, 16, 65-77.

Moen, P., \& Jull., P. M. M. (1995). Informing family policies: The uses of social research. Journal of Family and Economic Issues, 16, 79-107.

Child Support, Divorce Consequences, Economics, Employment of Women, Women

AFDC, Child Care, Employment, Low-income Families, Welfare Reform

Adoption, Child Quality, Human Capital, Open Adoption, Uncertainty

Children, Family, Household, Policy

Curricula, Education, Family Policy, Teaching

Basic Research, Child Support, Evaluation, Family Policy, Social Research, Policy Research, Social Policy, Social Science 
Appendix continued

Reference
Rettig, K. D., Tam, V. C.-W., \& Yellowthunde
L. (1995). Family policy and critical science
research: Facilitating change. Journal of
Family and Economic Issues, 16, 109-143.
Starrels, M. E. (1995). The evolution of fetal
protection policies. Journal of Family and
Economic Issues, 16, 313-340.

Garand, J. C., \& Monroe, P. A. (1995). Family leave legislation in the American states: Toward a model of state policy adoption. Journal of Family and Economic Issues, 16, 341-363.

Hennon, C. B., Jones, A., Hooper-Briar, K., \& Kopcanova, D. (1996). A snapshot in time: Family policy and the United National International Year of the Family. Journal of Family and Economic Issues, 17, 9-46.

Haas, L. (1996). Family policy in Sweden. Journal of Family and Economic Issues, 17, 47-92.

Baik, Y., \& Chung, J. Y. (1996). Family policy in Korea. Journal of Family and Economic Issues, 17, 93-112.

Randolph, S. M., \& Hassan, F. M. A. (1996). Structural adjustment and family policy in Africa: Lessons from Sudan. Journal of Family and Economic Issues, 17, 147-171.

Van Hook, M. P., \& Ngwenya, B. N. (1996). The majority legal status of women in Southern Africa: Implications for women and families. Journal of Family and Economic Issues, 17, 173-188.

Garey, A. I., \& Townsend, N. W. (1996). Kinship, courtship, and child maintenance law in Botswana. Journal of Family and Economic Issues, 17, 189-203.

Meyers, M. K. (1997). Cracks in the seams: Durability of child care in JOBS welfareto-work programs. Journal of Family and Economic Issues, 18, 357-377.

Meeks, C. B., Nickols, S. Y., \& Sweaney, A. L. (1999). Demographic comparisons of aging in five selected countries. Journal of Family and Economic Issues, 20, 223-250.

Spratlin, J. \& Holden, K. C. (2000). Women and economic security in retirement: Implications for social security reform. Journal of Family and Economic Issues, 21, 37-63.

Bok, M., \& Simmons, L. (2002). Post-welfare reform, low-income families and the dissolution of the safety net. Journal of Family and Economic Issues, 23, 217-238.
Keywords

Child Support, Critical Science, Family Policy

Employment Discrimination, Exclusionary Policies, Gender Roles, Occupational Health, Occupational Segregation

Family Leave, Family Policy, State Politics

Family Policy, Familycentric Policy Paradigm, Human Suffering, International Year of the Family

Children's Rights, Family Policy, Gender Equality, Sweden, Voluntary Parenthood

Family Policy, Korean Families

Family Policy, Poverty, Social Accounting Matrix, Structural Adjustment, Sudan

African Families, African Women, Legal Rights, Poverty

Botswana, Child Support, Kinship, Marriage

Child Care, Maternal Employment, Poverty, Welfare Reform

Aging, International, Gender Differences, Housing Alternatives

National Pensions, Australia, Sweden, Social Security Reform, Women

Poverty, Safety Net, TANF Reauthorization, Weflare Reform 
Appendix continued

Reference
Coffield, C. D. (2002). Welfare reform in
Indiana: The political economy of retricting
access to education and training. Journal of
Family and Economic Issues, 23, 261-284.
Miranne, K. B. (2002). Teen mothers and
welfare reform: Challenging the boundaries
of risk. Journal of Family and Economic
Issues, 23, 361-379.

Flouri, E. (2004). Parental background and political attitudes in British adults. Journal of Family and Economic Issues, 25, 245-254.

Trzcinski, E. (2005). Introduction to the symposium: Changing fortunes-Economic transitions, the European Union and families in Poland. Journal of Family and Economic Issues, 26, 185-194.

Alfred, M. V., (2005). Does Wisconsin works work? Perspectives of participating women and their employers. Journal of Family and Economic Issues, 26, 345-370.

Leung, H.-C., Lee, K-M. (2005). Immigration controls, life-course coordination, and livelihood strategies: A study of families living across the mainland-Hong Kong border. Journal of Family and Economic Issues, 26, 487-507.

Daniels, K. C., Rettig, K. D., \& delMas, R. (2006). Alternative formulas for distributing parental incomes at divorce. Journal of Family and Economic Issues, 27, 4-26.

Kolodinsky, J., Stewart, C., \& Bullard, A. (2006). Measuring economic and social impacts of membership in a community development financial institution. Journal of Family and Economic Issues, 27, 27-47.

Schramm, D. G. (2006). Individual and social costs of divorce in Utah. Journal of Family and Economic Issues, 27, 133-151.

Hansen, M. E., (2007). Using subsidies to promote the adoption of children from foster care. Journal of Family and Economic Issues, 28, 377-393.
Keywords

Education and Training, Inequality, Politcal Economy, Women

Social Policy, Teen At-risk, Teen Mother, Welfare Reform

National Child Development Study, Parental Background, Political Attitudes

None

Economic Self-sufficiency, Welfare Racism,

Welfare Reform, W-2, Wisconsin Works

Immigration Control, Life-course, Livelihood Strategies, Cross-boarder Families

Divorce, Income Distributions, Spousal Support

Banking, CDFI, Finance, Low income, Social Capital

Divorce, Economic Costs, Government, Marital Dissolution, Marriage

Adoption, Child Welfare, Foster Care, Policy, Subsidies

Family Resource Management

\begin{tabular}{ll}
\hline Reference & Keywords \\
\hline $\begin{array}{l}\text { Lown, J. M., \& Dolan, E. M. (1988). Financial } \\
\text { challenges in remarriage. Journal of Family }\end{array}$ & None \\
and Economic Issues, 9, 73-88. & \\
$\begin{array}{l}\text { Zick, C. D. (1988). Short-run adjustments in the } \\
\text { family's investment portfolio. Journal of }\end{array}$ & Family Investment Portfolios, Human Capital, \\
Family and Economic Issues, 9, 199-220. & Stock Adjustment Model \\
\hline
\end{tabular}


Appendix continued

Reference
Hogarth, J. M. (1989). Models of accepting an
early retirement incentive. Journal of Family
and Economic Issues, 10, 61-82.

Williams, F. L. (1989). Research in family financial counseling. Journal of Family and Economic Issues, 10, 181-204.

Danes, S. M., \& Morris, E. W. (1989). The factors affecting a family's plan to change its financial situation. Journal of Family and Economic Issues, 10, 205-215.

Coleman, M., \& Ganong, L. H. (1989). Financial management in stepfamilies. Journal of Family and Economic Issues, 10, 217-232.

Douthitt, R. A., \& Fedyk, J. M. (1989). The use of savings as a family resource management strategy to meet child rearing costs. Journal of Family and Economic Issues, 10, 233-248.

Fitzsimmons, V. S. (1989). Wife's role in monthly insurance expenditures. Journal of Family and Economic Issues, 10, 249-261.

Mugenda, O. M., Hira, T. K., \& Fanslow, A. M. (1990). Assessing the causal relationship among communication, money management practices, satisfaction with financial status, and satisfaction with quality of life. Journal of Family and Economic Issues, 11, 343-360.

Sharpe, D. L. \& Winter, M. (1991). Toward working hypotheses of effective management: Conditions, thought processes, and behaviors. Journal of Family and Economic Issues, 12, 303-323.

Avery, R. J., \& Stafford, K. (1991). Toward a scheduling congruity theory of family resource management. Journal of Family and Economic Issues, 12, 325-344.

Churaman, C. V. (1992). Financing of college education by single-parent and two-parent families. Journal of Family and Economic Issues, 13, 95-112.

Burton, J. R. (1992). Household technology: Implications for research and policy. Journal of Family and Economic Issues, 13, 383-394.

Zick, C. D. (1992). Do families share-and-sharealike? The need to understand intrahousehold resource allocations. Journal of Family and Economic Issues, 13, 407-419.

Hira, T. K., Fitzsimmons, V. S., Hafstrom, J. L., \& Bauer, J. W. (1993). Factors associated with expectations of household's future financial condition. Journal of Family and Economic Issues, 14, 237-256.
Keywords

Early Retirement, Older Workers, Pension, Retirement Incentives

Family Economic Well-being, Financial Counseling, Money Management, Quality of Life.

Family Finances, Consumption, Financial Satisfaction, Standard of Living

Financial Management, Marital Closeness, Parent-Child closeness, Remarriage, Stepfamilies

Canada, Children, Cost of Children, Family Size, Savings Behaviors

Financial Management, Gender Roles, Insurance

Communication, Financial Wellbeing, Money Management, Satisfaction with Finances, Satisfaction with Life

Management Theory, Managerial Behavior, Resource Management, Though Processes, Working Hypotheses

Congruity, Management, Production Process, Scheduling

College Education, Cost of Education, Family Finance, Intergenerational Transfers, Singleparent Families

Family Economics, Household Equipment, Household Technology, Household Time Use, Housework

Familial Altruism, Household Production, Intrahousehold Resource Allocations, Resource Sharing

Expectations, Future Financial Condition, Locus of Control, Perceptions, Rural 
Appendix continued

\begin{tabular}{ll}
\hline Reference & Keywords \\
\hline $\begin{array}{l}\text { Fitzsimmons, V. S., Hira, T. K., Bauer, J. W., } \\
\text { \& Hafstrong, J. L. (1993). Financial }\end{array}$ & $\begin{array}{c}\text { Family Resource Management, Financial } \\
\text { Management, Financial Problems, Scale }\end{array}$ \\
$\begin{array}{l}\text { management: Development of scales. Journal } \\
\text { of Family and Economic Issues, 14, 257-274. }\end{array}$ & $\begin{array}{l}\text { Development } \\
\text { Danes, S. M., \& Rettig, K. D. (1993). The role } \\
\text { of perception in the intention to change the }\end{array}$ \\
$\begin{array}{l}\text { Change Intentions, Family Finances, Locus of } \\
\text { Control, Satisfaction, Standard and Level }\end{array}$
\end{tabular}
family financial situation. Journal of Family and Economic Issues, 14, 365-389.

Hong, G. S., \& Kao, Y. E. (1997). Emergency fund adequacy of Asian Americans. Journal of Family and Economic Issues, 18, 127-145.

Hilton, J. M., \& Devall, E. L. (1997). The family economic strain scale: Development and evaluation of the instrument with single-and two-parent families. Journal of Family and Economic Issues, 18, 247-271.

Xiao, J. J., \& Anderson, J. G. (1997). Hierarchical financial needs reflected by household financial asset shares. Journal of Family and Economic Issues, 18, 333-355.

Fan, J. X., \& Zuiker, V. S. (1998). A comparison of household budget allocation patterns between Hispanic Americans and NonHispanic White Americans. Journal of Family and Economic Issues, 19, 151-174.

Moris, E. W. (1998). Household responses to major economic change in Poland: A theoretical framework. Journal of Family and Economic Issues, 19, 199-220.

Pallaszewska-Reindl, T. (1998). Polish households during the economic transformation. Journal of Family and Economic Issues, 19, 221-234.

Yeung, W. J., \& Hofferth, S. L. (1998). Family adaptations to income and job loss in the U.S. Journal of Family and Economic Issues, 19, 255-283.

Dolan, E. M., \& Stum, M. S. (1998). Economic security and financial management issues facing same-sex couples. Journal of Family and Economic Issues, 19, 343-365.

Thornton, M. C., \& White-means, S. I. (2000). Race versus ethnic heritage in models of family economic decisions. Journal of Family and Economic Issues, 21, 65-86.

Duncan, K. A., Zuiker, V. S., \& Heck, R. K. Z. (2000). The importance of household management for the business-owning family. Journal of Family and Economic Issues, 21, 287-311.

Asian Americans, Emergency Funds, Ethnicity

Coparenting, Divorce, Economic Strain, Measurement

Family Finance, Household Asset Portfolios, Household Financial Assets, Maslow's Theory, Saving Behavior

Consumer Demand, Ethnicity, Expenditure, Hispanics

Household Adapatation, Household Adjustment, Household Response, Poland

Poland, Economic Transformation, Polish Households

Economic Hardship, Geographic Mobility, Labor Force Participation, Public Assistance, Unemployment

Same-sex Couples, Homosexual Couples, Financial Management, Economic Security

Race, Ethnicity, Measurement Error, Culture, Informal Support

Buiness-owning Families, Dual-role Households, Family Businesses, Household Management, 1997 National Family Business Survey 
Appendix continued

Reference
Wakita, S., Fitzsimmons, V. S., \& Liao, T. F.
(2000). Wealth: Determinations of savings net
worth and housing net worth of pre-retired
households. Journal of Family and Economic
Issues, 21, 387-418.

Stum, M. S. (2001). Financing long-term care: Examining decision outcomes and systemic influences from the perspective of family members. Journal of Family and Economic Issues, 22, 25-53.

Goetting, M. A., \& Martin, P. (2001). Characteristics of older adults with written wills. Journal of Family and Economic Issues, 22, 243-264.

Muske, G., \& Winter, M. (2001). An in-depth look at family cash-flow management practices. Journal of Family and Economic Issues, 22, 353-372.

Hatcher, C. B. (2002). Wealth, reservation wealth, and the decision to retire. Journal of Family and Economic Issues, 23, 167-187.

Mano-Negrin, R. \& Katz, R. (2003). Money management patters of dual-earner families in Israel. Journal of Family and Economic Issues, 24, 27-48.

Beverly, S. G., McBride, A. M., \& Schreiner, M. (2003). A framework of asset-accumulation stages and strategies. Journal of Family and Economic Issues, 24, 143-156.

Finke, M. S., \& Huston, S. J., (2003). The brighter side of financial risk: Financial risk tolerance and wealth. Journal of Family and Economic Issues, 24, 233-256.

Chaulk, B., Johnson, P. J., \& Bulcroft, R. (2003). Effects of marriage and children on financial risk tolerance: A synthesis of family development and prospect theory. Journal of Family and Economic Issues, 24, 233-256.

Joo, S.-H., \& Grable, J. E. (2004). An exploratory framework of the determinants of financial satisfaction. Journal of Family and Economic Issues, 25, 25-50.

Baek, E., \& Hong, G.-S. (2004). Effects of family life-cycle stages on consumer debts. Journal of Family and Economic Issues, 25, 359-385.

Hogarth, J. M., Anguelov, C. E., \& Lee, J. (2005). Who has a bank account? Exploring changes over time, 1989-2001. Journal of Family and Economic Issues, 26, 7-30.
Keywords

Attitudes, Intergenerational Support, Net worth, Race or Ethnic Origin Savings

Long-term Care, Estate Planning, Qualitative Research, Aging

Bequests, Estate Planning, Inheritances, Older Adults, Wills

Cash-flow Management, Family Financial Management, Qualitative Research

Labor Supply, Retirement, Wealth

Conception, Divorce, Marriage, Taiwan, Unemployment

Financial Education, Financial Services, Saving, Unbanked

Risk Tolerance, Wealth Accumulation

Family Development, Prospect Theory, Risk Tolerance

Financial Behavior, Rinancial Literacy, Financial Satisfaction, Financial Stress

Credit Card Debt, Double-hurdle Model, Installment Debt, Life-Cycle Stages

Bank Accounts, Financial Services, Lowincome Poverty, Unbanked 
Appendix continued

\begin{tabular}{lc}
\hline Reference & Keywords \\
\hline $\begin{array}{l}\text { Lucey, T. A. (2005). Assessing the reliability } \\
\text { and validity of the Jump\$tart Survey of }\end{array}$ & $\begin{array}{c}\text { Assessment, Financial Education, Jump\$tart } \\
\text { Coalition, Social Bias, Calidity }\end{array}$ \\
$\begin{array}{l}\text { Financial Literacy. Journal of Family and } \\
\text { Economic Issues, 26, 283-294. }\end{array}$ & \\
Cha, K.-W., Weagley, R. O., \& Reynolds, L. & Borrowing, College, Heckman, Parental \\
(2005). Parental borrowing for dependent & Investment \\
children's higher education. Journal of & \\
Family and Economic Issues, 26, 299-321. & \\
Kim, H., \& DeVaney, S. A. (2005). The & Health and Retirement Study, Multinomial \\
selection of partial or full retirement by older & Logistic Regression, Retirement \\
workers. Journal of Family and Economic & \\
Issues, 26, 371-394. & \\
Chan, A. H.-N. (2005). Live-in foreign domestic & Family Dynamics, Hong Kong, Middle-class \\
workers and their impact on Hong Kong's & Families, Paid Domestic Workers, Parental \\
middle class families. Journal of Family and & Roles \\
Economic Issues, 26, 509-528.
\end{tabular}

Finke, M. S., Huston, S. J., \& Sharpe, D. L. (2006). Balance sheets of early boomers: Are they different from pre-boomers? JFEI, 27, 542-561.

Lai, C. W. (2006). Determinants of portfolio efficiency losses in US self-directed pension accounts. Journal of Family and Economic Issues, 27, 601-625.

Allen, M. W., Edwards, R., Hayhoe, C. R., \& Leach, L. (2007). Imagined interactions, family money management patterns and coalitions, and attitudes toward money and credit. Journal of Family and Economic Issues, 28, 3-22.

Collins, J. M. (2007). Exploring the design of financial counseling for martgage borrowers in default. Journal of Family and Economic Issues, 28, 207-226.

Johnson, P. S. (2007). Credit card practices of Vietnamese and Laotian newcomers to Canada: A 10-year longitudinal perspective. Journal of Family and Economic Issues, 28, 227-246.

Peng, T.-C., M., Bartholomae, S., Fox, J. J., \& Cravener, G. (2007). The impact of personal finance education delivered in high school and college courses. Journal of Family and Economic Issues, 28, 265-284.

Gafova, I. B. (2007). Your money or your life: Managing health, managing money. Journal of Family and Economic Issues, 28, 285-303.

Lee, Y. G., Lown, J. M., \& Sharpe, D. L. (2007). Predictors of holding consumer and mortgage debt among Older Americans. Journal of Family and Economic Issues, 28, 305-320.

Defined Contribution Plan, Efficiency Losses, Portfolio Choices

Credit Cards, Family Differentiation, Imagined Interactions: Money Management Patterns, Parent-Teen Communication

Credit Counseling, Foreclosure, Mortgage Default Counseling

Consumer Acculturation, Credit Cards, Laotians, Vietnamese, Refugees

College Students, Financial Literacy, Household Savings, Personal Finance

Credit Card Debt, Health Behaviors, NonCollateralized Debt, Obesity, Smoking

Aging, Consumer Debts, Mortgages, Economic well-being 
Appendix continued

\begin{tabular}{lc}
\hline Reference & Keywords \\
\hline $\begin{array}{l}\text { O'Neill, B. (2007). Overcoming intertia: Do } \\
\text { automated saving and investing strategies }\end{array}$ & Automatic Investing, Automatic Retirement \\
work? Journal of Family and Economic & Plan Enrollment, 401(K) Plans \\
Issues, 28, 321-335. & \\
\hline
\end{tabular}

Health and Health Services

\begin{tabular}{ll}
\hline Reference & Keywords \\
\hline
\end{tabular}

Miners, L. (1988). Individual vs. Household determinants of the demand for medical care: A study of rural families. Journal of Family and Economic Issues, 9, 33-54.

Phipps, S. A. A. (1991). Family systemes functioning, family health roles, and utilization of physical health services. Journal of Family and Economic Issues, 12, 23-41.

Williams, F. L., Hagler, A., Martin, M. A., Pritchard, M., \& Bailey, W. C. (1991). Predictors of out-of-pocket medical expenditures in low-income households. Journal of Family and Economic Issues, 12, 43-62.

Leonard, B. J., Brust, J. D., \& Patterson, J. (1991). Home care reimbursement for technology-dependent children: Its impact on parental distress. Journal of Family and Economic Issues, 12, 63-76.

Monroe, P. A. (1993). Family health care decision making. Journal of Family and Economic Issues, 14, 7-25

Kronenfeld, J. J. \& Glik, D. C. (1995). Unintentional injury: A major health problem for young children and youth. Journal of Family and Economic Issues, 16, 365-393.

Axtell, S. A. M., Garwick, A. W., Patterson, J., Bennett, F. C., \& Blum, R. W. (1995). Unmet service needs of families of young children with chronic illnesses and disabilities. Journal of Family and Economic Issues, 16, 395-411.

Williams, S. D. (1995). Integrating family service system from the inside out: A view from the bureaucratic trenches. Journal of Family and Economic Issues, 16, 413-424.

Hong, G. S. \& Hong, S.-Y. (1997). Health care of American Indian Elderly: Determinants of the perceived difficult obtaining access to health care. Journal of Family and Economic Issues, 18, 33-47.

Scannell, E., \& Hong, G.-S. (1997). Family home businesses: Who buys health insurance? Journal of Family and Economic Issues, 18, 407-425.
None

Family Circumplex Model, Family Health Roles, Family Systems Functioning, Utilization of Health Services

Health Costs, Low-Income, Medicaid, Medical Expenses, Medicare

Chronic Disease, Home Care, Psychological Adaptation, Social Adjustment, TechnologyDependent Children

Family Decision Making, Family Economics, Health Care, Health Maintenance Organizations

Child Health, Epidemiology, Policy, Unintentional Injury

Chilhood Chronic Illness, Childhood Disability, Family Needs, Health Care, Satisfaction with Services

At-risk Children, Community-based Services, Family-centered Services, Public

Administration, Service Integration

American Indian Elderly, Difficulty Gaining Access to Health Services, Elderly Health Care

Family Home Business, Health Care, Health Insurance 
Appendix continued

\begin{tabular}{|c|c|}
\hline Reference & Keywords \\
\hline $\begin{array}{l}\text { Chi, P. S. K. \& Hsin, P.-L. (1999). Medical } \\
\text { utilization of health expenditure of the elderly } \\
\text { in Taiwan. Journal of Family and Economic } \\
\text { Issues, 20, 251-270. }\end{array}$ & Elderly Healthcare, Caregiving \\
\hline $\begin{array}{l}\text { LeRoy, B. W., \& Johnson, D. M. (2002). Open } \\
\text { road or blind alley? Welfare reform, mothers, } \\
\text { and children with disabilities. Journal of } \\
\text { Family and Economic Issues, 23, 323-337. }\end{array}$ & $\begin{array}{l}\text { Child Care, Children with Disabilities, Welfare } \\
\text { Reform }\end{array}$ \\
\hline $\begin{array}{l}\text { Abdel-Ghany, M., \& Wang, M. Q. (2003). } \\
\text { Contemporaneous and intertemporal } \\
\text { relationship between the consumer of licit and } \\
\text { illicit substances by youth. Journal of Family } \\
\text { and Economic Issues, 24, 281-289. }\end{array}$ & $\begin{array}{l}\text { Alcohol, Cigarettes, Gateway Hypothesis, } \\
\text { Marijuana, Youth Risky Behavior }\end{array}$ \\
\hline $\begin{array}{l}\text { Finke, M. S., \& Huston, S. J., (2003). Factors } \\
\text { affecting the probability of choosing a risky } \\
\text { diet. Journal of Family and Economic Issues, } \\
\text { 24, 291-303. }\end{array}$ & Diet Choice, Risk, Time Preference \\
\hline $\begin{array}{l}\text { Luo, F., Abdel-Ghany, M., \& Ogawa, I. (2003). } \\
\text { Cigarette smoking in Japan: Examination of } \\
\text { mypoic and rational models of addictive } \\
\text { behaviors. Journal of Family and Economic } \\
\text { Issues, 24, 305-317. }\end{array}$ & $\begin{array}{l}\text { CigaretteSsmoking in Japan, Myopic Addictive } \\
\text { Models, Rational Addictive Models, Risky } \\
\text { Behavior }\end{array}$ \\
\hline $\begin{array}{l}\text { Chen, Z. Yen, S. T., \& Eastwood, D. B. (2007). } \\
\text { Does smoking have a causal effect on weight } \\
\text { reduction? Journal of Family and Economic } \\
\text { Issues, 28, 49-57. }\end{array}$ & $\begin{array}{l}\text { Body Mass Index, Censored Regressor, } \\
\text { Overweight, Simultaneously Equations } \\
\text { System, Smoking }\end{array}$ \\
\hline $\begin{array}{l}\text { Sharpe, D. L., \& Baker, D. L. (2007). Financial } \\
\text { issues associated with having a child with } \\
\text { autism. Journal of Family and Economic } \\
\text { Issues, 28, 247-264. }\end{array}$ & $\begin{array}{l}\text { Autism, Caregiving, Financial Burden, Special } \\
\text { Needs Planning }\end{array}$ \\
\hline
\end{tabular}

Housing

\begin{tabular}{ll}
\hline Reference & Keywords \\
\hline $\begin{array}{l}\text { Chi, P. S. K. (1988). Family structure and } \\
\text { housing consumption: A study of Chinese }\end{array}$ & None \\
families in Taiwan. Journal of Family and & \\
Economic Issues, 9, 55-72. & \\
Hudson, J. R. (1988). Pioneer artists and middle & Housing, Inner Cities, Neighborhood \\
class settlers: Lifestyle variables and & Gentrification, Urban Social Change \\
neighborhood succession. Journal of Family & \\
and Economic Issues, 9, 250-263. & Crowding, Family, Family Theory, Living \\
Beeghley, L., \& Donnelly, D. (1989). The & Space \\
consequences of family crowding: A & \\
theoretical synthesis. Journal of Family and & \\
Economic Issues, 10, 83-102. & Housing, Housing Attributes, Lifecycle \\
Lodl, K. A., Gabb, B. S., \& Combs, E. R. & \\
(1990). The importance of selected housing & \\
features at various stages of the life cycle. & \\
Journal of Family and Economic Issues, 11, & \\
383-395.
\end{tabular}


Appendix continued

\begin{tabular}{|c|c|}
\hline Reference & Keywords \\
\hline $\begin{array}{l}\text { Meeks, C. B. (1992). Balancing regulation and } \\
\text { affordability of housing. Journal of Family } \\
\text { and Economic Issues, 13, 373-382. }\end{array}$ & Affordability, Housing, Housing Regulation \\
\hline $\begin{array}{l}\text { Laux, S. C., \& Cook, C. C. (1994). Female- } \\
\text { headed households in nonmetropolitan areas: } \\
\text { Housing and demographic characteristics. } \\
\text { Journal of Family and Economic Issues, 15, } \\
\text { 301-316. }\end{array}$ & $\begin{array}{l}\text { Female-headed Households, Housing } \\
\text { Affordability, Housing Characteristics, } \\
\text { Poverty }\end{array}$ \\
\hline $\begin{array}{l}\text { Combs, E. R., \& Park, S. (1994). Housing } \\
\text { affordability among elderly female heads of } \\
\text { household in nonmetropolitan areas. Journal } \\
\text { of Family and Economic Issues, 15, 317-328. }\end{array}$ & $\begin{array}{l}\text { Elderly Women, Female Heads, Rural Housing } \\
\text { Affordability }\end{array}$ \\
\hline $\begin{array}{l}\text { Cook, C. C., \& Bruin, M. J. (1994). } \\
\text { Determinants of housing quality: A } \\
\text { comparison of white, African-American, and } \\
\text { Hispanic single-parent women. Journal of } \\
\text { Family and Economic Issues, 15, 329-347. }\end{array}$ & $\begin{array}{l}\text { Crowding, Housing, Housing Cost Burden, } \\
\text { Housing Satisfaction, Single Parents }\end{array}$ \\
\hline $\begin{array}{l}\text { Memken, J. A., \& Canabal, M. E. (1994). } \\
\text { Housing tenure, structure, and crowding } \\
\text { among Latino households. Journal of Family } \\
\text { and Economic Issues, 15, 349-365. }\end{array}$ & $\begin{array}{l}\text { Crowding, Housing Conditions, Latinos, } \\
\text { Minorities }\end{array}$ \\
\hline $\begin{array}{l}\text { White, B. J., Peaslee, J., \& LaQuarta, J. (1994). } \\
\text { Comparing housing affordability and quality } \\
\text { among disability households: The United } \\
\text { States and its regions. Journal of Family and } \\
\text { Economic Issues, 15, 367-380. }\end{array}$ & Disability, Housing Affordability \\
\hline $\begin{array}{l}\text { Chi, P. S. K. \& Laquatra, J. (1998). Profiles of } \\
\text { housing cost burden in the United States. } \\
\text { Journal of Family and Economic Issues, 19, } \\
\text { 175-193. }\end{array}$ & $\begin{array}{l}\text { Housing Cost Burden, Minority Households, } \\
\text { Single-risk Groups, Multi-risk Groups }\end{array}$ \\
\hline $\begin{array}{l}\text { Cook, C. C., Crull, S. R., Fletcher, C. N., } \\
\text { Hinnant-Bernard, T., \& Peterson, J. (2002). } \\
\text { Meeting family housing needs: Experiences } \\
\text { of rural women in the midst of welfare } \\
\text { reform. Journal of Family and Economic } \\
\text { Issues, 23, 285-316. }\end{array}$ & Housing, Welfare Reform, Women and Housing \\
\hline $\begin{array}{l}\text { Arnold, J. E., \& Lang, U. A. (2007). Changing } \\
\text { American home life: Trends in domestic } \\
\text { leisure and storage among middle-class } \\
\text { families. Journal of Family and Economic } \\
\text { Issues, 28, 23-48. }\end{array}$ & $\begin{array}{l}\text { Clutter, Dual-Earner Families, Home Spaces, } \\
\text { Leisure Time, Suburban History }\end{array}$ \\
\hline
\end{tabular}

Intergenerational or Interhousehold Exchanges

\begin{tabular}{ll}
\hline Reference & Keywords \\
\hline $\begin{array}{l}\text { Williams, F. L. (1988). Value provided by } \\
\text { interfamily economic exchange of goods and }\end{array}$ & $\begin{array}{c}\text { Exchange, Household Production, Nonmoney } \\
\text { Income, Mexican-Americans }\end{array}$ \\
services in two cultures. Journal of Family & \\
and Economic Issues, 9, 221-239. & \\
Grigsby, J. S. (1989). Adult children in the & $\begin{array}{c}\text { Intergenerational Relations, Living } \\
\text { parental household: Who benefits? Journal of }\end{array}$ \\
Family and Economic Issues, 10, 293-309. & $\begin{array}{l}\text { Arrangements, Multiple Generation } \\
\text { Households }\end{array}$ \\
\hline
\end{tabular}


Appendix continued

\begin{tabular}{l} 
Reference \\
\hline Williams, F. L. (1991). Interfamiliy economic \\
exchange: A function of culture or \\
economics? Journal of Family and Economic \\
Issues, 12, 235-252. \\
Puang, T. C., \& Metzen, E. J. (1993). \\
Interhousehold grants in peninsular Malaysia: \\
Impact of grantors' characteristics on amount \\
of grants given. Journal of Family and \\
Economic Issues, 14, 317-342. \\
Bian, J. (1996). Parental monetary investments \\
in children: A focus on China. Journal of \\
Family and Economic Issues, 17, 113-139.
\end{tabular}

Kao, Y. E., Hong, G.-S., \& Widdows, R. (1997). Bequest expectations: Evidence from the 1989 Survey of Consumer Finances. Journal of Family and Economic Issues, 18, 357-377.

Coleman, M., \& Ganong, L. H. (1998). Attitudes toward inheritance following divorce and remarriage. Journal of Family and Economic Issues, 19, 289-314.

Lune, L. S. V., Winter, M., Morris, E. W., Gutkowska, K., \& Jezewska-Zychowica, M. (1999). Interhousehold transfers of goods and services and reported well-being among Polish households. Journal of Family and Economic Issues, 20, 333-366.

Culter, L. J., Cho, J., Yust, B. L., \& Frankling, E. M. (1999). Generational differences in orientations to coresidence in Chongju, South Korea. Journal of Family and Economic Issues, 20, 367-386.

Stum., M. S. (2000). Families and inheritance decisions: Examining non-titled property transfers. Journal of Family and Economic Issues, 21, 177-202.

Bjarnason, T. (2000). Grooming for success? The impact of adolescent society on early intergenerational social mobility. Journal of Family and Economic Issues, 21, 319-342.

MacDonald, M., \& Koh, S.-K. (2003). Consistent motives for inter-family transfers: Simple altruism. Journal of Family and Economic Issues, 24, 73-97.

Cowley, E. T., Paterson, J., \& Williams, M. (2004). Traditional gift giving among Pacific families in New Zealand. Journal of Family and Economic Issues, 25, 431-444.

Cao, H. (2006). Time and financial transfers within and beyond the family. Journal of Family and Economic Issues, 27, 375-400.
Keywords

Cultural Differences, Goods and Services, Intergeneration Exchanges, MexicanAmericans, Quality of Life

Grants, Interhousehold, Malaysia, Necessity Goods

Human Capital Investments, One-child Policy, Parental Investments, Quantity and Quality of Children

Altruism, Bequest, Inheritance, Intergenerational Transfers

Inheritance, Wills, Intergenerational Obligations, Divorce, Remarriage, In-laws

Poland, Interhousehold Transfers, Well-being

Social Welfare, Intergenerational Living Arrangements

Family Inheritance, Non-titled Property, Intergenerational Transfers, Estate Planning, Fairness

Adolescent Society, Culture Capital, Extracurricular Activities, Social Capital, Social Mobility

Family Transfers, Inheritance, Mid-life Adults

Pacific Families, Traditional Gift Giving

Charitable Donation, Family Transfer HRS, Time and Financial Transfers, Volunteer Work 
Appendix continued

\begin{tabular}{ll}
\hline Reference & Keywords \\
\hline $\begin{array}{l}\text { Hayhoe, C. R., \& Stevenson, M. L. (2007). } \\
\text { Financial attitudes and inter vivos resource }\end{array}$ & $\begin{array}{c}\text { Family Resource Management Theory, } \\
\text { Intergenerational Transfers, Older Adults, } \\
\text { transfers from older parents to adult children. }\end{array}$ \\
$\begin{array}{l}\text { Journal of Family and Economic Issues, 28, } \\
\text { 123-135. }\end{array}$ \\
\hline
\end{tabular}

Poverty and Public Assistance

Reference Keywords

Tuttle, R. C. (1989). Poverty over the family life cycle. Journal of Family and Economic Issues, 10, 267-291.

Trzcinski, E. (1995). An ecological perspective on family policy: A conceptual and philosophical framework. Journal of Family and Economic Issues, 16, 7-33.

Hao, L. (1995). Poverty, public assistance, and children in intact and single-mother families. Journal of Family and Economic Issues, 16, 181-205.

Corcoran, M., \& Adams, T. (1995). Family and neighborhood welfare dependency and sons' labor supply. Journal of Family and Economic Issues, 16, 239-264.

Pepper, J. V. (1995). Dynamics of the intergenerational transmission of welfare receipt in the United States. Journal of Family and Economic Issues, 16, 265-279.

Santiago, A. M. (1995). Intergenerational and program-induced effects of welfare dependency: Evidence from the National Longitudinal Survey of Youth. Journal of Family and Economic Issues, 16, 281-306.

Coe, R. D., \& Hill, D. H. (1998). Food stamp participation and reasons for nonparticipation: 1986. Journal of Family and Economic Issues, 19, 107-130.

Driscoll, A. K., \& Moore, K. A. (1999). The relationship of welfare receipt to child outcomes. Journal of Family and Economic Issues, 20, 85-113.

De Hann, L. G., \& MacDermid, S. M. (1999). Identity development as a mediating factor between urban poverty and behavioral outcomes for junior high school students. Journal of Family and Economic Issues, 20, 123-148.

Douthitt, R. A. (2000). "Time to do the chores?" Factoring home-production needs into measures of poverty. Journal of Family and Economic Issues, 21, 7-22.
Family Structure, Poverty

Ecological Model, Ecological Perspective, Family Policy, Human Ecology Theory, Philosophy of Family Policy

Child Development, Poverty, Public Assistance, Single Motherhood

Labor Supply, Poverty, Underclass, Welfare Culture

Aid to Families with Dependent Children, Intergenerational Welfare, Panel Study of Income Dynamics

AFDC Dependency, Blacks, Latinos, Welfare Dependency

Barriers to Participation, Food Stamp Participation, Multinomial Logit

Child Outcomes, Poverty, Welfare Identity Development, Urban Poverty

Poverty, Poverty Measurement, Time Poverty 
Appendix continued

\begin{tabular}{l} 
Reference \\
\hline Curtis, K. A. (2002). Financial penalites under \\
the Temporary Assistance for Needy Families \\
Program: Policy discourse and strategies for \\
reform. Journal of Family and Economic \\
Issues, 23, 239-260. \\
Trzcinski, E. (2002). Middle school children's \\
perceptions on welfare and poverty: An \\
exploratory, qualitative study. Journal of \\
Family and Economic Issues, 23, 339-259. \\
Kwon, H.-K., Zuiker, V. S., \& Bauer, J. W. \\
(2004). Factors associated with the poverty \\
status of Asian immigrant hosueholders by \\
citizenship status. Journal of Family and \\
Economic Issues, 25, 101-120.
\end{tabular}

Caputo, R. K. (2004). The impact of intergenerational head start participation on success measures among adolescent children. Journal of Family and Economic Issues, 25, 199-223.

Bae, J. P. \& Gardner, K. E. (2004). Low-income children's participation in a public health insurance program in Georgia. Journal of Family and Economic Issues, 25, 225-243.

Randolph, K. A., Rose, R. A., Fraser, M. W., \& Orthner, D. K. (2004). Examining the impact of changes in maternal employment on high school completion among low-income youth. Journal of Family and Economic Issues, 25, 279-299.

Mimura, Y., \& Mauldin, T. A. (2005). American young adults' rural-to-urban migration and timing of exits from poverty spells. Journal of Family and Economic Issues, 26, 55-76.

Roy, K. M. (2005). Transitions on the margins of work and family life for low-income African-American fathers. Journal of Family and Economic Issues, 26, 77-100.

Bronson, D. E., Kunovich, S., \& Frysztacki, K. (2005). The impact of the economic transition in Poland on vulnerable populations. Journal of Family and Economic Issues, 26, 225-238.

Bystydzienski, J. M. (2005). Negotiating the new market: women, families, women's organizations, and the economic transition in Poland. Journal of Family and Economic Issues, 26, 239-265.

Fletcher, C. N., Grasky, S. B., \& Nielsen, R. B. (2005). Transportation hardship: Are you better off with a car? JFEI, 26, 323-343.

Livermore, M. M., \& Powers, R. S. (2006). Employment of unwed mothers: The role of government and social support. Journal of Family and Economic Issues, 27, 479-494.
Keywords

Sacntions, TANF, Welfare Reform

Child Development, Child Outcomes, Maternal Employment, Poverty, Welfare Reform

Acculturation, Asian, Human Capital, Immigrants, Poverty

Adolescent Achievement, Early Childhood Education, Head Start

Children's Health, Enrollment, Medicaid, Medical Insurance, SCHIP

Dropout, Maternal Employment, Poverty, Timevarying, Welfare Reform

Internal Migration, Poverty, Young Adults

African-American Families, Fatherhood, Work/ family

Economic Transition, Poland, Poverty, Social Welfare

Economic Restructuring, Families, Women's organization, Women in Poland

Economic Wellbeing, Material Hardship, Transportation

Employment, Government Support, Social Support, Unwed Mothers 
Appendix continued

\begin{tabular}{|c|c|}
\hline Reference & Keywords \\
\hline $\begin{array}{l}\text { Garasky, S. \& Stewart, S. D. (2007). Evidence } \\
\text { of the effectiveness of child support and } \\
\text { visitation: Examining food insecurity among } \\
\text { children with nonresident fathers. Journal of } \\
\text { Family and Economic Issues, 28, 105-121. }\end{array}$ & $\begin{array}{l}\text { Child Support, Father Involvement: Father } \\
\text { Visitation, Food Insecurity, National Survey } \\
\text { of America's Families }\end{array}$ \\
\hline $\begin{array}{l}\text { Ponthiere, G. (2007). Monetizing longevity } \\
\text { gains under welfare interdependencies: An } \\
\text { exploratory study. Journal of Family and } \\
\text { Economic Issues, 28, 449-469. }\end{array}$ & $\begin{array}{l}\text { Altruism, Family, Longevity, Standards of } \\
\text { Living, Welfare, Interdependencies }\end{array}$ \\
\hline $\begin{array}{l}\text { Roche, K. M., Astone, N. M., \& Bishai, D. } \\
\text { (2007). Out-of-school care and youth problem } \\
\text { behaviors in low-income, urban areas. } \\
\text { Journal of Family and Economic Issues, 28, } \\
\text { 471-488. }\end{array}$ & $\begin{array}{l}\text { Low-income Families, Out-of-School Care, } \\
\text { Problem Behaviors, Transition into } \\
\text { Adolescence }\end{array}$ \\
\hline $\begin{array}{l}\text { Simmons, L. A., Dolan, E., M., \& Braun, B. } \\
\text { (2007). Rhetoric and reality of economic self- } \\
\text { sufficiency among rural, low-income mothers: } \\
\text { A longitudinal study. Journal of Family and } \\
\text { Economic Issues, 28, 489-505. }\end{array}$ & $\begin{array}{l}\text { Economic Self-Sufficiency, Labor Force } \\
\text { Participation, Marriage, Rural, Welfare } \\
\text { Reform }\end{array}$ \\
\hline $\begin{array}{l}\text { Mauldin, T. A., \& Mimura, Y. (2007). Marrying, } \\
\text { unmarrying, and poverty dynamics among } \\
\text { mothers with children living at home. Journal } \\
\text { of Family and Economic Issues, 28, 566-582. }\end{array}$ & $\begin{array}{l}\text { Marital Status, Mothers, Poverty, Poverty } \\
\text { Dynamics, Two-Way Transition Model }\end{array}$ \\
\hline
\end{tabular}

Rural Families

\begin{tabular}{ll}
\hline Reference & Keywords \\
\hline $\begin{array}{l}\text { Price, D. Z., \& Dunlap, L. J. (1988). Stress and } \\
\text { coping of adults and young adults in }\end{array}$ & $\begin{array}{c}\text { Socioeconomic Stress, Young Adults, Rural } \\
\text { Communities, Coping Strategies }\end{array}$ \\
economically uncertain rural areas. Journal of & \\
Family and Economic Issues, 9, 123-144. & \\
Krannich, R. S., Riley, P. J., \& Leffler, A. & Economic Satisfaction, Life Events, Rural \\
(1988). Perceived stress among & Families, Stress \\
nonmetropolitan Utah residents. Journal of & \\
Family and Economic Issues, 9, 281-296. & \\
Price, D. Z., \& Dunlap, L. J. (1988). Family use & Community Services, Rural Families, \\
of community services in economically & Socioeconomic Stress \\
stressed rural counties. Journal of Family and & \\
Economic Issues, 9, 314-330. & \\
Marotz-Baden, R. (1988). Income, economic & \\
satisfaction, and stress in two-generational & Economic Satisfaction, Farm Families, Income, \\
farm families. Journal of Family and & Stress \\
Economic Issues, 9, 331-356. & \\
Haldeman, V. A., \& Peters, J. M. (1988). Using & \\
resistance resources to reduce stress: A study & \\
of rural Nevadans. Journal of Family and & Managing Stress, Resiliance, Resources, Rural \\
Economic Issues, 9, 357-366. & Families, Stress \\
Robertson, E. B., \& Shoffner, S. M. (1989). Life & \\
satisfaction of young adults reared in low- & \\
income Appalachian families. Journal of & Appalachia, Life Satisfaction, Poverty \\
Family and Economic Issues, 10, 5-17. & \\
\hline
\end{tabular}


Appendix continued

\begin{tabular}{ll}
\hline Reference & Keywords \\
\hline Ackerman, N. M., Jenson, G. O., \& Bailey, D.
\end{tabular}

Ackerman, N. M., Jenson, G. O., \& Bailey, D. (1991). Domains explaining the life quality of dairy farm couples. Journal of Family and Economic Issues, 12, 107-130.

Wilson, S. M., Marotz-Baden, R., \& Holloway, D. P. (1991). Stress in two-generation farm and ranch families. Journal of Family and Economic Issues, 12, 199-216.

Wozniak, P. J., Draughn, P. S. \& Knaub, P. K. (1993). Domains of subjective well-being in farm men and women. Journal of Family and Economic Issues, 14, 97-114.

Danes, S. M., \& Solheim, C. A. (1993). Satisfaction and role quality perceptions of farm women employed off the farm. Journal of Family and Economic Issues, 14, 115-143.

Walson, C. O., \& Fitzsimmons, V. S. (1993). Financial manager's perception of rural household economic well-being: Development and testing of a composite measure. Journal of Family and Economic Issues, 14, 193-214.

Bauer, J. W., Hira, T. K., Wilhelm, M. S., Varcoe, K. P., \& Thomas, S. (1993). The determinants of worry over chronic health condition for rural couples. Journal of Family and Economic Issues, 14, 275-291.

Sumarwan, U., \& Hira, T. K. (1993). The effects of perceived locus of control and perceived income adequacy on satisfaction with financial status of rural households. Journal of Family and Economic Issues, 14, 343-364.

Hilton, J. M., Martin, S. K., \& Haldeman, V. A. (1994). Using psychometric analysis to evaluate the construct valudity and reliability of the coping response indices. Journal of Family and Economic Issues, 15, 201-221.

Simmons, L. A., Braun, B. Wright, D. W., \& Miller, S. R. (2007). Human capital, social support, and economic well-being among rural, low-income mothers: A latent growth curve analysis. Journal of Family and Economic Issues, 28, 635-652.
Life Quality, Rural Families, Work Satisfaction

Family business, Family Stress, Rural Families, Two-Generations

Satisfaction, Off-farm Employment, Goal Achievement

Family role, Farm Women, Labor Force Participation, Role Quality, Satisfaction

Economic Well-being, Financial Well-being

Chronic Health, Economic Well-being, Rural Couples, Worry

Perceived Income Adequacy, Perceived Locus of Control, Satisfaction with Financial Status, Socioeconomic Variables

Assessment of Coping, Coping Indices, Family Resource Management, Family Stress

Economic Well-being, Human Capital, Rural, Social Support, Welfare Reform

Time Use

Reference

Olson, P. N., Ponzetti, J. J., \& Olson, G. I. (1989). Time demands on families: Is there a bottom line? Journal of Family and Economic Issues, 10, 311-323
Keywords

Time-Use, Household Production, Housework 
Appendix continued

Reference
Douthitt, R. A., Zick, C. D., \& McCullough, J.
(1990). The role of economic and
demographic factors in explaining time-use of
single and married mothers. Journal of
Family and Economic Issues, 11, 23-51.
Mauldin, T., \& Meeks, C. B. (1990). Time
allocation of one- and two-parent mothers.
Journal of Family and Economic Issues, 11,
53-69.
Key, R. J., \& Sanik, M. M. (1990). The effect of
homemaker's employment status on
children's time allocation in single- and two-
parent families. Journal of Family and
Economic Issues, 11, 71-88.

Bryant, W. K., \& Wang, Y. (1990). Time together, time apart: An analysis of wives' solitary time and shared time with spouses. Journal of Family and Economic Issues, 11, 89-119.

Hiatt, A. R., \& Godwin, D. D. (1990). Use of time preferences for time allocation among urban, employed, married women. Journal of Family and Economic Issues, 11, 161-181.

Meeks, C. B. \& Mauldin, T. (1990). Children's time in structured and unstructured leisure activities. Journal of Family and Economic Issues, 11, 257-281.

Hilton, J. M. (1990). Differences in allocation of family time spent on household tasks among single-parent, one-earner, and two-earner families. Journal of Family and Economic Issues, 11, 283-298.

Sanik, M. M. (1990). Parents' time use: A 19671986 comparison. Journal of Family and Economic Issues, 11, 299-316.

Hafstrom, J. L., \& Paynter, M. (1991). Time use satisfaction of wives: Home, farm, and labor force workload. Journal of Family and Economic Issues, 12, 131-143.

Owen, A. J. (1991). Time and time again: Implications of time perception theory. Journal of Family and Economic Issues, 12, 345-359.

Bryant, W. K. (1992). Human capital, time use, and other family behavior. Journal of Family and Economic Issues, 13, 395-405.

Robinson, J. P. (1996). Time, housework, and the rest of life. Journal of Family and Economic Issues, 17, 213-229.

Fenstermaker, S. (1996). The dynamics of time use: Context and meaning. Journal of Family and Economic Issues, 17, 231-243.
Keywords

Married Mothers, Single Mothers, Time Use

Married Mothers, Single Mothers, Time Use

Children, Female LFP, Married Mothers, Single Mothers, Time Use

Marriage, Time Use

Women's LFP, Household Production, Time Preferences, Time Use

Children, Leisure Time, Time Use

Dual-Earners, Housework, Single-Earners, Single-Parents, Time Use

Childcare, Gender Roles, Time Use

Rural Families, Role Overload, Time Use

Family Resource Management, Household Production, Time Use

General Human Capital, Human Capital, Specific Human Capital, Time Use

Gender Differences, Household Production, Social Change and Measurement Issues, Trends in Use of Time

Context, Dynamics, Housework, Measurement, Time 
Appendix continued

\begin{tabular}{ll}
\hline Reference & Keywords \\
\hline $\begin{array}{l}\text { Michael, R. T. (1996). Money illusion: The } \\
\text { importance of household time use in social }\end{array}$ & $\begin{array}{c}\text { Poverty and Children, Real Income, Social } \\
\text { Policy, Time Value }\end{array}$ \\
policy making. Journal of Family and & \\
Economic Issues, 17, 245-260. & \\
Harvey, A. S. (1996). The measurement of & Household, Survey Methodology, Time Use \\
household time allocation: Data needs, & Allocation \\
analytical approaches, and standardization. & \\
Journal of Family and Economic Issues, 17, & \\
261-280. & \\
Nickols, S. Y., \& Ayieko, M. (1996). Spot & \\
observation: Advantages and disadvantages & Comparison of Research Methods, Household \\
for household time use research. Journal of & Activities, Spot Observation, Time Use \\
Family and Economic Issues, 17, 281-295. & Studies \\
Hanna, S., DeVaney, S. \& Martin, A. (1996). & \\
Using a computer simulation game to teach & Computer Software, Family Time Use, \\
family time use concepts Journal of Family & Overload, Simulation, Work/Family Roles
\end{tabular}

family time use concepts. Journal of Family and Economic Issues, 17, 297-311.

Sanik, M. M. \& Stafford, K. (1996). Children's time in household work: Estimation Issues. Journal of Family and Economic Issues, 17, 313-325.

Trzcinski, E. (1996). Effects of uncertainty and risk on the allocation of time of married women. Journal of Family and Economic Issues, 17, 327-350.

Kolodinsky, J., \& LaBrecque, J. (1996). The allocation of time to grocery shopping: A comparison of Candadian and U.S. households. Journal of Family and Economic Issues, 17, 393-408.

Avery, R. J., Bryant, W. K., Douthitt, R. A., \& McCullough, J. (1996). Lessons from the past, directions for the future. Journal of Family and Economic Issues, 17, 409-418.

Doo, K.-J., \& Ju, I.-S. (1997). Time use of employed mothers in Korea: A cross-cultural comparison. Journal of Family and Economic Issues, 18, 179-189.

Roxburgh, S. (2002). Racing through life: The distribution of time pressures by roles and role resources among full-time workers. Journal of Family and Economic Issues, 23, 121-145.

Dosman, D., Fast, J., Chapman, S. A., \& Keating, N. (2006). Retirement and productive activity in later life. Journal of Family and Economic Issues, 27, 401-419.

Lin, T.-F., \& Chen, J. (2006). Custodial fathersDo they work more or fewer hours? Journal of Family and Economic Issues, 27, 513-522.

Children, Household Work, Time Use

Divorce, Female Labor Supply, Income Uncertainty, Risk and Uncertainty, Time Use

Enjoyment of Time, Logit, Price Information Search

Families, Households, Measurement, Public Policy, Time Use

Outside Household Help, Time Use, Work Overload

Gender Differences, Job Conditions, Roles, Time Pressures, Volunteer Work

Aging, Productive Activity, Retirement, Time Use

Custody, Father, Working Hours 
Appendix continued

\begin{tabular}{ll}
\hline Reference & Keywords \\
\hline $\begin{array}{l}\text { Weagley, R. O., Chan, M.-L., \& Yan, J. (2007). } \\
\text { Married couples' time allocation decisions }\end{array}$ & Divorce, Market Work, Household Production \\
and marital stability. Journal of Family and & \\
Economic Issues, 28, 507-525. & \\
Garcia, I., Molina, J. A., \& Navarro, M. (2007). & Europe, Leisure Time, Satisfaction, Spouses \\
How satisfied are spouses with their leisure & \\
time? Evidence from Europe. Journal of & \\
Family and Economic Issues, 28, 546-565. &
\end{tabular}

\section{References}

Anderson, D. M., Morgan, B. L., \& Wilson, J. B. (2002). Perceptions of family-friendly policies: University versus corporate employees. Journal of Family and Economic Issues, 23, 73-92.

Daly, K. J. (2003). Family theory and the theories families live by. Journal of Marriage and Family, 65, 771-784.

Delgadillo, L., Sorensen, S., \& Coster, D. C. (2004). An exploratory study of preparation for future care among older Latinos in Utah. Journal of Family and Economic Issues, 25, 51-78.

Hennon, C. (1988). From the editor. Lifestyle: Family and Economic Issues, 9, 3-4.

Israelsen, C. L., \& Hatch, S. (2005). Proactive research: Where art thou? Financial Counseling and Planning, 16, 91-96.

Reynolds, L. M., \& Abdel-ghany, M. (2001). Consumer sciences research: A two-decade comparison, 1980s and 1990s. Family and Consumer Sciences Research Journal, 29, 382-440.

Xiao, J. J. (2006). A thank you note to guest editors and reviewers and the acceptance rate of JFEI. Journal of Family and Economic Issues, 27, 1-3.

Zelizer, V. A. (1994). The social meaning of money. New York: Basic Books. 